\title{
ADAM17 as a Therapeutic Target in Multiple Diseases
}

\author{
Joaquín Arribas ${ }^{1,2, *}$ and Cary Esselens ${ }^{2}$
}

${ }^{1}$ Institució Catalana de Recerca i Estudis Avançats (ICREA), Spain and ${ }^{2}$ Medical Oncology Research Program, Vall d'Hebron Hospital Research Institute, Vall d'Hebron Instute of Oncology (VHIO) and Universitat Autonoma de Barcelona (UAB), Barcelona, Spain

\begin{abstract}
As a metalloproteinase specialized in releasing membrane-tethered proteins, A Disintegrin and A Metalloproteinase 17 (ADAM17), also known as Tumor necrosis factor- $\alpha$ Converting Enzyme (TACE) or less commonly CD156q, has received more than its share of attention. This is mainly because major contemporary pathologies like cancer, inflammatory and vascular diseases seem to be connected to its cleavage abilities. The involvement in such a broad spectrum of diseases is due to the large variety of substrates that ADAM17 is able to cut. ADAM17 can activate growth factors or inactivate receptors by shedding their extracellular domain from the cell membrane. Similarly, it can detach cells by cleaving cell adhesion molecules. Some of these proteolytic events are part of cleavage cascades known as Regulated Intramembrane Proteolysis and lead to intracellular signaling. It is therefore clear that ADAM17 literally fulfills a key role in diverse processes and pathologies, making it a prime target for developing therapies. Here we review the role of ADAM17 in health and disease and highlight the problems to overcome for ADAM17 to mature towards a therapeutically valuable target.
\end{abstract}

Key Words: TACE, degradome, tumor, inflammation, inhibitor, shedding.

\section{STRUCTURE}

As the other ADAMs, ADAM17 is a modular type I protein that contains, in addition to the signal peptide, four functionally distinct extracellular domains followed by a transmembrane region and a cytoplasmic tail (Fig. 1) [1].

\section{Prodomain}

The prodomain keeps ADAM17 in an inactive state by blocking the metalloproteinase catalytic site. It has been recently shown that the so called "cysteine switch" mechanism, that operates in many Matrix Metalloproteinases (MMPs) and ADAMs and consists of the coordination of the zinc ion by a cysteine located in the prodomain, is not necessary for keeping the precursor of ADAM17 in an inactive state [2]. It is removed by furin-like proprotein convertases in the transGolgi compartment by cleavage at the consensus $\mathrm{RX}(\mathrm{R} / \mathrm{K}) \mathrm{R}$ motif $[3,4]$. The synthesis and purification of isolated prodomains from different ADAMs, including ADAM17, has confirmed that they can act as potent, selective inhibitors of the mature active forms of the metalloproteinase [5-7].

In addition to its inhibitory function, the prodomain also acts as a chaperone and protects the enzyme from degradation during transport through the secretory pathway [2].

\section{Metalloproteinase Domain}

Out of the 25 human ADAMs, 13, including ADAM17, bear the characteristic reprolysin-type active site (HEXGH-

*Address correspondence to this author at the Medical Oncology Research Program, Vall d'Hebron University Hospital Research Institute, Psg. Vall d'Hebron 119-129, Universitat Autonoma de Barcelona (UAB), 08035 Barcelona, Spain; Tel: +34 93274 6026; Fax: +34 93489 3884;

E-mail: jarribas@ir.vhebron.net
XXGXXHD) involved in coordinating the zinc atom [8]. This Zn-binding motif is followed by the "Met turn", which is the signature of the enzymes belonging to the Metzincin clan [9].

The metalloproteinase domain of ADAM17 is functionally the most relevant. Knockout mice expressing a deleted form of ADAM17 lacking the $\mathrm{Zn}$ binding domain display a severe phenotype characterized by the death of most embryos around birth [10] that is similar to that of animals lacking the entire gene [11].

How ADAM17 recognizes its many substrates is still far from clear. The primary sequence of the cleavage site does not seem to play a determinant role. In fact, cleavage sites differ between different ADAM17 substrates and there are no similarities in the surrounding sequences. Moreover, mutagenesis of residues around or even at the cleavage site do not prevent the shedding of some ADAM17 substrates [12-15]. However, using a Biotin-LAQA-P1'-P2'-SSK(DNP)$\mathrm{NH} 2$ template, based on the cleavage site found in the proinflammatory cytokine pro-Tumor Necrosis Factor $\alpha$ (pro$\mathrm{TNF} \alpha$ ), recombinant TACE was shown to prefer lipophilic amino acids at the P1' position and basic amino acids at the P2' position [16, 17].

Evidence suggests that the distance from the membrane may be important for determining the cleavage, since this almost invariably occurs at 10-15 amino acids from the plasma membrane. For example, deletion of more than 10 amino acids from the extracellular juxtamembrane region of proTNF $\alpha$, blocked the release of soluble TNF $\alpha$ [18]. However, additional features have been suggested to play a role in recognition of the juxtamembrane regions to be cleaved, such as the tertiary structure of the extracellular domain [12].

(C) 2009 Bentham Science Publishers Ltd. 


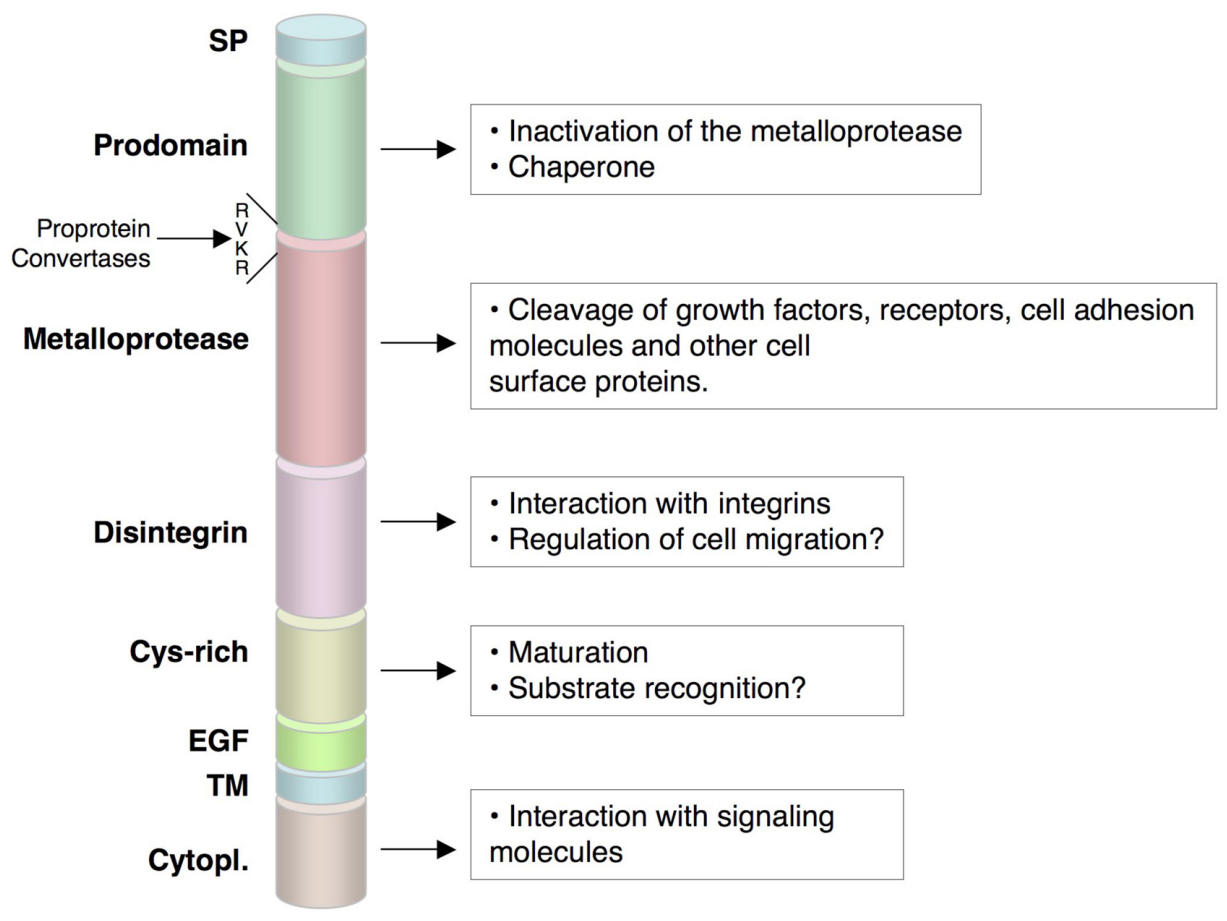

Fig. (1). Schematic showing the different domains of ADAM17 and the functions that they fulfill. See text for details.

It has also been suggested that the cysteine-rich domain of ADAM17 specifically interacts with certain substrates (see below). However, to date, the number of such substrates is very low and, for the recognition of most ADAM17 substrates, the participation the cysteine-rich domain has not been substantiated.

\section{Disintegrin Domain}

Because of its high degree of homology, the disintegrin domain of ADAMs was named after the snake venom disintegrins, which bind specific integrins [19]. Integrins are heterodimeric receptors consisting of $\alpha$ and $\beta$ chains with a ligand-binding extracellular domain and a short cytoplasmic tail. They support cell migration by providing the connection between the cell cytoskeleton and the extracellular matrix. In addition to a structural role, they also trigger signaling pathways (reviewed in [20]). The binding to extracellular ligands initiates intracellular signaling that, in turn, regulates different aspects of the cellular behavior such as cell adhesion, cytoskeleton reorganization and cell polarity [21].

As is the case for other ADAMs, the interaction of ADAM17 with integrins is promiscuous: ADAM17 interacts with different integrins and a given integrin interacts with different ADAMs, including ADAM17. Although the functional outcome of ADAMs and integrins is not clear [22], it has been shown that ADAM17 impairs cell migration through binding to $\alpha 5 \beta 1$, one of its cognate integrins [23].

\section{Cysteine-Rich Domain}

The Cys-rich domain is regarded as a regulatory domain that acts at different levels. It is important for the recognition of particular substrates [24] as well as for the maturation of ADAM17 [25]. Modulation of disulfide bonds in the cys- teine-rich domain affects L-selectin shedding. Using a cellbased ADAM17 reconstitution assay, Wang and colleagues demonstrated that the cysteine-X-X-cysteine motifs are critical for L-selectin cleavage [26]. Similarly, analysis of ADAM17 deletion constructs shows that the Cys-rich domain is required for the shedding of Interleukin-1 ReceptorII shedding, but not for the shedding of proTNF $\alpha$ or the TNF $\alpha$ receptor, p75TNF [24]. In line with these findings, the Cys-rich domain of ADAM10 seems to participate in the recognition and cleavage of Ephrin A5 [27]. Ephrins are cellassociated ligands for Eph tyrosine kinase receptors and signal repulsion of adjacent cells upon receptor binding [28]. After binding to its cognate receptor, the Ephrin-A5 ligand is cleaved in trans by ADAM10 [29]. This cleavage event depends on the formation of a de novo high affinity binding site for the Cys-rich domain of ADAM10 by the Ephrin A5receptor complex, properly positioning ADAM10 for cleavage. It remains to be established if other ADAMs, including ADAM17, use a similar mechanism to recognize certain substrates.

The importance of the Cys-rich domain in the maturation of ADAM17 has been unveiled characterizing the CHO-M2 cell line, that bears a mutation in a cysteine, located in the Cys-rich domain [30]. Functional analyses confirmed that Cys600 was indispensable for the maturation and activity of ADAM17 [3].

\section{Cytoplasmic Domain}

The 130 amino acid long cytoplasmic domain binds to a variety of intracellular signaling molecules including Protein Kinase C (PKC), Extracellular signal-regulated kinase (ERK) and mitotic arrest deficient 2 (MAD2), but the exact functional role of these interactions is still largely unknown 
(reviewed in [8]). Although intracellular signals can influence ADAM17 catalytic activity, this seems to be independent from the cytoplasmic domain [24] and is probably mediated through other transmembrane proteins.

It has recently been shown that a proline-rich stretch in the cytoplasmic domain of ADAM10, the closest relative to ADAM17, is important for the correct basolateral positioning of ADAM10 in polarized epithelial cells, resulting in Ecadherin cleavage and promoting cell migration upon correct localization [31]. Presently, the identity of the intracellular protein that controls this process is not clear, though Synapse Associated Protein-97 (SAP97) interacts with this region of ADAM10 and is responsible for correct insertion of ADAM10 in synaptic membranes [32]. Interestingly, SAP97 also interacts with the cytoplasmic domain region of ADAM17, via the third PDZ domain of SAP97 [33].

Intriguingly, even though the cytoplasmic domain interacts with proteins and can be phosphorylated in response to phorbol ester treatment, that also induces shedding, its deletion has apparently no effects on ADAM17 catalytic activity [24]. This observation is even more puzzling considering that the cytoplasmic domain contains a potential tyrosine phosphorylation site in a Src homology 2 domain binding site, (KKLDKQYESL ${ }^{705}$ ), as well as a potential Src homology 3 domain binding site, (PAPQTPGR ${ }^{738}$ ).

\section{THE DEGRADOME OF ADAM17}

The discovery of new ADAM17 substrates has been continuous during the last decade and, currently, there are over fifty known substrates (Table 1). The substrates of ADAM17 are functionally and structurally heterogeneous and include membrane anchored growth factors and cytokines, receptors, cell adhesion molecules and ectoenzymes. In many instances the cleavage by ADAM17 has been shown to regulate the function of a given substrate leading to activation, inactivation or modulation of the activity (reviewed in [34, 35]).

\section{Membrane-Anchored Ligands}

Many soluble growth factors and cytokines are synthesized as transmembrane proteins (see Table 1). The shedding of the extracelluar domain of membrane-anchored growth factors and cytokines by ADAM17 constitutes a clear example of how metalloproteinases control signaling pathways. Evolutionary, this system is widespread and ADAM17 orthologs can be found in mouse, zebra fish, roundworm and the fruit fly. The main advantage of this regulatory mechanism is that the response to environmental cues can be swift, rapidly switching a pathway either on or off, and independent from the slower transcription-translation system. For example, the release of transforming growth factor- alpha (TGF- $\alpha$ ), a ligand for the Epidermal Growth Factor Receptor (EGFR), constitutes a straightforward activation process, because the membrane-bound proTGF- $\alpha$ is largely inactive [36]. A number of other EGFR ligands are similarly inactive when membrane anchored (reviewed in [8]).

In the case of TNF- $\alpha$, the ADAM17 cleavage results in a transition between two active forms with different properties [37]. The human carcinoma cell line Colo205, is resistant to the soluble TNF- $\alpha$, but sensitive to membrane-associated proTNF- $\alpha$ [38]. Furthermore, mice expressing an uncleavable form of proTNF- $\alpha$ are unable to undergo septic shock, demonstrating the fundamental role proteolytic cleavage has in this pathological process [39]. Similarly, the EGF-like ligands known as neuregulins, are fully active even when membrane bound and cleavage by ADAM17 represents the conversion of a physically restricted growth factor into a diffusible isoform [40].

\section{Receptors}

It is not surprising that, in addition to ligands, the ADAM17 degradome includes many receptors, since the cleavage of this type of molecule offers an additional way to regulate the response of the cell to growth factors and cytokines. Not only will a shed receptor be unable to transmit signals to the cell, but it can act as a ligand-sequestring scavenger. This is nicely illustrated by the shedding of the receptors for TNF- $\alpha$ by ADAM17 and the subsequent sequestering of TNF- $\alpha$ by the soluble receptors, which prevent the binding of the cytokine to the full-length receptors [37].

In contrast to the negative impact on TNF- $\alpha$ signaling, ADAM17 can be an activator of certain receptors. The wellstudied case of Notch, a receptor that determines the developmental fates of mainly neuronal and hematopoietic cell populations, constitutes an excellent example of receptor activation by proteolysis [41]. Following ligand binding, ADAM17 releases the extracellular domain of Notch while the so-called "stub", consisting of the transmembrane and cytoplasmic domain, stays behind in the membrane. This stub now becomes a substrate for Regulated Intramembrane Proteolysis (RIP) by $\gamma$-secretase. In turn, the released intracellular domain of Notch can translocate to the nucleus where it regulates the expression of its target genes [42]. Other receptors cleaved by ADAM17 such as ErbB4 [43] and the cell adhesion molecules N-cadherin [44] and CD44 [45], have been shown to signal through a similar mechanism.

\section{Cell Adhesion Molecules}

Highlighting its importance in the regulation of cell-cell interactions, ADAM17 was shown to act on a large group of cell adhesion molecules (Table 1) [10, 46-51]. An obvious effect of the shedding of cell adhesion molecules is the weakening of cell-cell interactions (reviewed in [22]). In addition, the shedding of certain cell adhesion proteins is relevant in signal transduction. As in the case of Notch, the shedding of CD44 by ADAM17 and other metalloproteinases, is followed by a RIP event, that releases the intracellular domain (ICD) of CD44. The ICD translocates to the nucleus, where it regulates the transcription of target genes [52].

\section{ADAM17 DYSFUNCTION AND DISEASE}

Despite the remarkably large number of ADAM17 substrates identified during the last decade (see Table 1), to date, most of the proposed pathological roles of the metalloproteinase are related to just a few, namely, TNF- $\alpha$, the ligands of the EGFR and the Amyloid Precursor Protein (APP) (Fig. 2). However, given the central role of these molecules in many biological processes, the number of 
diseases in which ADAM17 has been suggested as a therapeutic target has grown exponentially in the last years.

\section{Table 1. ADAM17 Substrates}

\begin{tabular}{|c|c|}
\hline Substrate & Reference \\
\hline \multicolumn{2}{|l|}{ Cytokines and Growth Factors } \\
\hline proTNF- $\alpha$ (pro-tumor necrosis factor- $\alpha$ ) & {$[150,62]$} \\
\hline proTGF- $\alpha$ (pro-transforming growth factor- $\alpha$ ) & {$[10]$} \\
\hline proAR (pro-amphiregulin) & [151] \\
\hline proBTC (pro-betacellulin) & $\begin{array}{c}{[50,152} \\
153]\end{array}$ \\
\hline proEPR (pro-epiregulin) & [152] \\
\hline proEPG (pro-epigen) & [154] \\
\hline proNRG $\alpha-2 C$ (pro-neuregulin- $\alpha-2 C$, Heregulin) & [155] \\
\hline proHB-EGF (pro-heparin-binding epidermal growth factor) & {$[156]$} \\
\hline pref-1 (preadipocyte factor 1 ) & [157] \\
\hline Fractalkine (CX3CL1) & [158] \\
\hline SEMA4D (semaphorin 4D) & [159] \\
\hline LAG3 (lymphocyte activation gen 3) & [160] \\
\hline Dll1 (delta-like 1) & [161] \\
\hline Kit ligand-1 and -2 & {$[162]$} \\
\hline MICA (MHC-class I-related chain A/B) & [163] \\
\hline \multicolumn{2}{|l|}{ Receptors } \\
\hline p75 TNF- $\alpha$ RII (tumor necrosis factor- $\alpha$ receptor II) & {$[10]$} \\
\hline p55 TNF- $\alpha$ RI (tumor necrosis factor- $\alpha$ receptor I) & {$[24]$} \\
\hline p75NTR (neurotrophin receptor) & {$[164]$} \\
\hline IL-6R $\alpha$ (interleukine- 6 receptor- $\alpha$ ) & [165] \\
\hline IL-1RII (interleukine-1 receptor type II) & [24] \\
\hline IL-15R $\alpha$ (interleukine-15 receptor $\alpha$ ) & {$[166]$} \\
\hline TrkA neurotrophin receptor & [167] \\
\hline GHR (growth hormone receptor) & {$[168]$} \\
\hline M-CSFR (macrophage colony stimulating factor receptor) & [169] \\
\hline SorLA receptor (Vps10-p domain receptor) & {$[170]$} \\
\hline LDL receptor & {$[170]$} \\
\hline AXL receptor & [170] \\
\hline PTP-LAR (protein tyrosine phosphatase LAR receptor) & [171] \\
\hline EPCR (endothelial protein C receptor) & [172] \\
\hline ACE2/ SARS-CoV Receptor & {$[16]$} \\
\hline NPR (neuronal pentraxin receptor) & {$[173]$} \\
\hline HER4 & [174] \\
\hline
\end{tabular}

\begin{tabular}{|c|c|}
\hline Notch & [175] \\
\hline CD30 & [176] \\
\hline CD40 & [177] \\
\hline GPIb $\alpha$ (glycoprotein Ib- $\alpha)$ & [178] \\
\hline \multicolumn{2}{|l|}{ Adhesion molecules } \\
\hline ICAM-1 (intercellular adhesion molecule-1) & {$[51]$} \\
\hline VCAM-1 (vascular cell adhesion molecule-1) & [49] \\
\hline NCAM (neural cell adhesion molecule) & [179] \\
\hline ALCAM (activated leukocyte cell adhesion molecule) & [46] \\
\hline L1-CAM & [180] \\
\hline RA175/SynCAM1 & [181] \\
\hline Dsg-2 (desmoglein 2) & [46] \\
\hline L-selectin & [10] \\
\hline Collagen XVII & {$[48]$} \\
\hline Nectin-4 & [47] \\
\hline $\mathrm{CD} 44$ & [50] \\
\hline \multicolumn{2}{|l|}{ Other molecules } \\
\hline APP (amyloid precursor protein) & [182] \\
\hline APLP2 (APP-like protein 2) & [183] \\
\hline Ebola virus glycoprotein GP & [184] \\
\hline Carbonic anhydrase IX & [185] \\
\hline Cellular prion protein & [186] \\
\hline Klotho & [187] \\
\hline MUC-1 & [188] \\
\hline $\mathrm{C} 4.4 \mathrm{~A}$ & [189] \\
\hline
\end{tabular}

The ligands of the EGFR are synthesized as type I transmembrane molecules that can be proteolytically activated by ADAMs in general, but particularly by ADAM17 [8]. This makes ADAM17 a key therapeutical target for diseases where dysregulation of the EGFR signaling pathway plays a pathogenic role such as cancer.

The dysregulation of TNF- $\alpha$ is connected to several inflammatory disorders, including rheumatoid arthritis (RA) [53] and osteoarthritis [54], inflammatory bowel disease (IBD) [55], stroke [56], endotoxic shock [57] and multiple sclerosis (MS) [58]. Although other proteinases have been shown to be proteolyticaly active towards the membraneanchored proTNF- $\alpha$ [59-61], ADAM17 appears to be the most efficient in vivo [62]. For this reason, ADAM17 is considered an effective therapeutic target in TNF- $\alpha$ mediated disorders.

The APP protein is the precursor for the amyloid beta (A $\beta$ ) peptide, that when produced at high levels, accumulates in the form of amyloid plaques in the brain of Alzheimer's disease patients [63]. The $A \beta$ is formed by the sequencial 


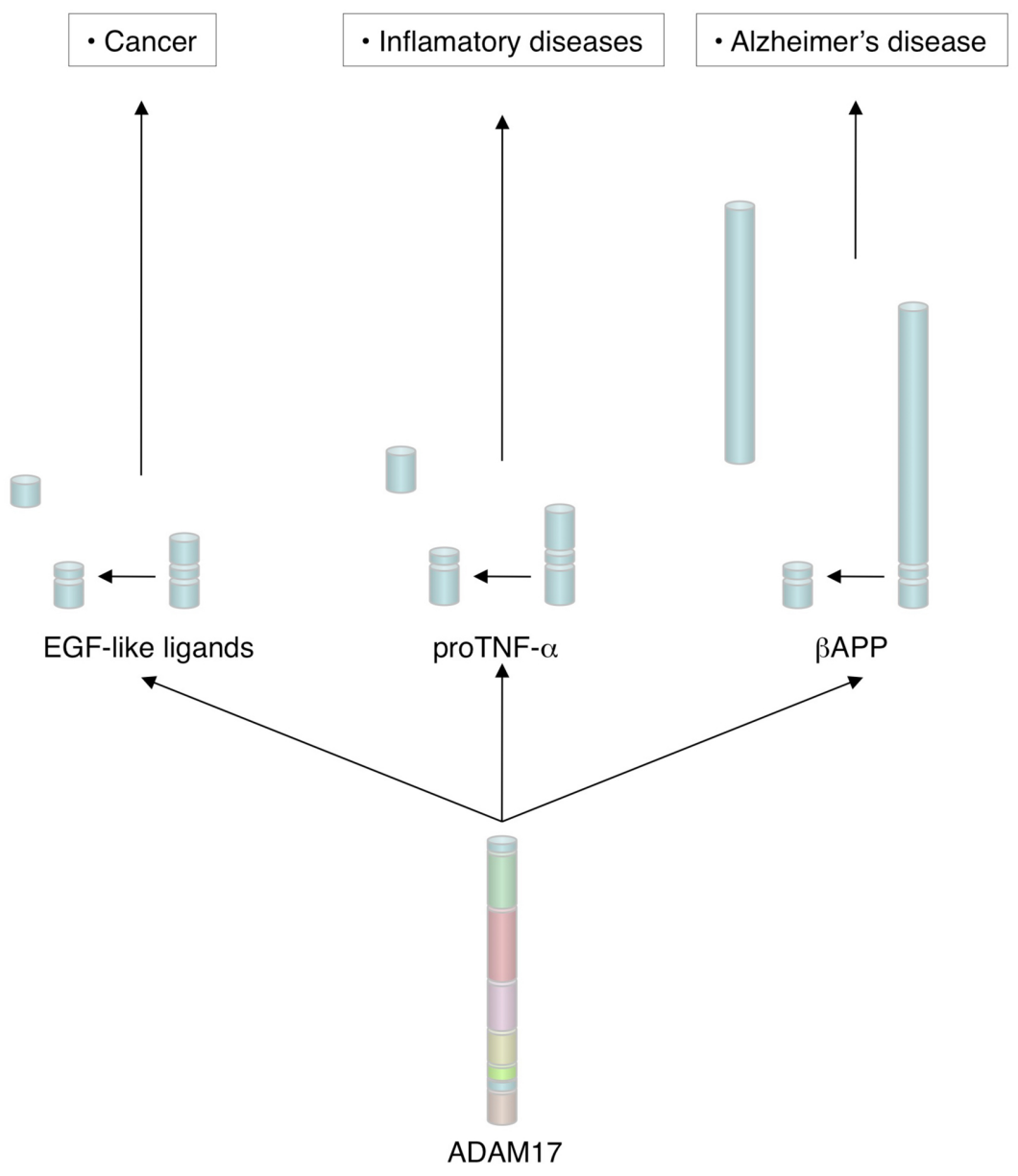

Fig. (2). Schematic showing the types of diseases in which ADAM17 is involved, through the cleavage of EGF-like ligands, proTNF-alpha and betaAPP.

cleavage by the, so-called $\beta$ - and $\gamma$-secretases [64]. A third secretase, alpha-secretase, cleaves withing the $\mathrm{A} \beta$ peptide precludig its production. ADAM17 seems to be endowed with $\alpha$-secreatese activity $[65,66]$ and, thus, its activation has been suggested as a therapeutic approach in the treatment of Alzheimer's disease [67].

Although to date only these ADAM17 substrates seem to be relevant in human disease, it cannot be discarded that the number of disease-relevant transmembrane proteins cleaved by ADAM17 could expand even more in the near future.

\section{Cancer}

The EGFR (also known as HER1 receptor or ErbB1), is the prototype of a family that includes three additional members: HER2 (also known as Neu or ErbB2), HER3 and HER4 (also known as ErbB3 and ErbB4, respectively) [68]. Upon ligand binding, the receptors undergo homo- or heterooligomerization and activation. Activated HER receptors transduce signals through a plethora of intracellular factors that, ultimately, regulate the expression of groups of genes that control cellular proliferation, migration, adhesion, differentiation and apoptosis [68].

The ligands for the HER receptors are synthesized as transmembrane molecules that are cleaved by ADAM17 and ADAM10 and perhaps other ADAMs, particularly when overexpressed [8]. In several instances cleavage activates the ligand (see, for example [36]), that, as a soluble form can bind and activate the HER receptors.

The clearly established involvement of HER receptors in cancer progression has led to the implementation of different therapeutic strategies including monoclonal antibodies targeting the ectodomain of the receptors and tyrosine kinase inhibitors [69]. In principle, inhibition of ADAM17 and, hence, immobilization of several EGFR ligands, could complement current anti-EGFR tumor therapies, particularly when ADAM17 is overactivated. This hypothesis has lead to the characterization of the role of ADAM17 in different types of tumors.

\section{Lung Cancer}

The leading cause of cancer-related death is lung carcinoma, a devastating disease responsible each year for 1.3 million deaths (WHO (2004). Deaths by cause, sex and mortality stratum). Histologically, lung cancers are classified as non-small-cell lung cancer (NSCLC), adenocarcinoma, squamous-cell carcinoma, or large-cell undifferentiated carcinoma [70]. The EGFR pathway is overactivated in most patients with NSCLC, and, consistent with a causal role of this overactivation in the pathogenesis of the disease, an inhibitor of the tyrosine kinase of the EGFR (Gefitinb) has shown efficacy in a large-scale clinical trial for NSCLC. 
Unfortunately, due to primary or acquired resistance to the drug, the overall response was much lower than expected [71].

One of the mechanisms of resistance to Gefitinib, involves the autocrine production of soluble HER receptor ligands mediated, at least in part, by ADAM17 [72]. In fact, ADAM17 protein levels are upregulated in the majority of human lung cancer samples analyzed and the levels of ADAM17 correlate with the activation of HER3 [72]. Apparently, the increased levels of ADAM17 result in an increased production of soluble heregulin, an ADAM17 substrate and a ligand for HER3. High levels of soluble heregulin leads to HER3 activation, which is unaffected by gefitinib, and subsequent promotion of cell growth, migration and resistance to apoptosis [72]. Consistent with these results, gefitinib insensitivity correlates with heregulin expression and treatment of resistant cells with INCB3619, an inhibitor of ADAM17 and ADAM10, blocks heregulin release and sensitizes a Gefitinib-resistant human NSCLC cell line to Gefitinib treatment [72]. This study shows that ADAM17 inhibitors may impair one of the mechanisms of resistance to tyrosine kinase inhibitors targeting the EGFR and indicate that the combinantion of tyrosine kinase inhibitors and inhibitors of ADAM17 may be an effective way to treat some lung cancers.

\section{Breast Cancer}

Breast cancer is the most frequent malignancy among women in the industrialized countries. There are nearly 1 million new cases per year, worldwide (WHO World Cancer Report (June 2003)).

Different components of the EGFR pathway, such as HER2, are overactivated and play a causal role in breast cancer progression [73]. ADAM17 is frequently overexpressed in breast cancers [36] and its overexpression is associated with tumor progression and metastasis [74]. Apparently, the overexpression of ADAM17 is due to transcriptional [74] as well as post-transcriptional mechanisms [75].

Genetic or biochemical inhibition of ADAM17 leads to the prevention of the shedding of EGFR ligands in different cells, including cells derive from breast tumors [36, 74, 76]. Blocking the shedding of proTGF- $\alpha$ results in the inactivation of the EGFR, indicating that ADAM17 inhibitors can be useful to target the EGFR pathway also in mammary tumors.

\section{Other Cancers}

In human colorectal tumors, ADAM17 levels and activity are elevated compared to healthy control tissue [77]. ADAM17 protein expression is also higher in pancreatic ductal carcinoma [78], prostate cancer [79] and ovarian cancer [80] and increased ADAM17 protein expression correlated with disease severity in oral squamous cell carcinoma [81].

In these tumors the overexpression of ADAM17 tends to correlate with the activation of the EGFR pathway. Thus, inhibitors of the metalloproteinase would block EGFR signaling and could be therapeutic alone or in combination with other anti-EGFR drugs. Different experiments support this hypothesis. Nude mice injected with oral squamous carcinoma cells had slower tumor growth when treated with the ADAM17/ADAM10 inhibitor INCB3619 [82]. RNAi suppression of ADAM17 in renal carcinoma cells led to decreased cell proliferation [83]. Similarly, treatment of U87 human brain tumor cells with ADAM17-specific RNAi led to decreased invasion [84].

\section{Inflammatory Diseases}

\section{Rheumatoid Arthritis}

Rheumatoid arthritis is an autoimmune disease which affects approximately $1 \%$ of the world's population. It is characterized by chronic systemic inflammation [85]. Rheumatoid joints contain inflammatory infiltrates that spread from the synovia [86]. Eventually, this synovitis leads to the degradation of the joint surface, resulting in loss of function.

The TNF- $\alpha$ signaling pathway is overactivated in the inflammatory infiltrates and induces the production of the degrading enzymes that contribute to the erosion of cartilage and bone [87]. Human RA cartilage displays upregulated ADAM17 mRNA expression [88], indicating that the metalloproteinase is responsible, at least in part, for the overactivation of the TNF- $\alpha$ pathway. In turn, chronic hypoxia, one of hallmarks of rheumatoid arthritis seems to contribute to the upregulation of ADAM17. It has been recently shown that this low oxygen condition, along with TNF- $\alpha$ itself, upregulates the transcription of ADAM17, through the transcription factor hypoxia inducible factor HIF-1, in synovial cells [89]. Confirming the importance of this positive feedback loop in the pathology of RA, there is a positive correlation between ADAM17 and HIF-1 protein levels in RA synovium [89].

Neutralization of the TNF- $\alpha$ signaling pathway, by blocking the interaction of the cytokine with its cognate receptors, has been demonstrated as a feasible approach to treating RA. For example, positive results have been reported using etanercept, a TNF receptor p75 $\mathrm{IgGFc}$ fusion protein [90].

Since ADAM17 cleaves proTNF-alpha to yield a soluble form, inhibition of this enzyme is a feasible therapeutic intervention (review see [91]). This hypothesis has been proven in different animal models. Mice immunized against collagen and treated with LPS (lipopolysaccharides) develop RA symptoms. In this model, inhibitors of ADAM17 show efficacy, both prophylactically and therapeutically [92]. Confirming the therapeutic value of ADAM17 inhibitors, their effect is comparable, or even higher than that of drugs directed direclty against TNF- $\alpha$ [92].

The effect of ADAM17 inhibitors has also been analyzed in other frequently used RA models such as collageninduced arthritis (CIA) in rats and mice [93]. DPC333, a selective ADAM17 inhibitor, suppressed the maximal response by $50 \%$ in the CIA model [94]. Furthermore, the ADAM17 inhibitor GW-3333 was shown to be exceptionally potent and long lasting in a rat arthritis model [95].

\section{Inflammatory Bowel Disease}

Ulcerative colitis and Crohn's disease, collectively known as inflammatory bowel disease, are major causes of lifetime morbidity [96]. Although these diseases are often 
differentiated clinically, they share many characteristics including an exacerbated mucosal inflammatory response caused by overactivation of TNF- $\alpha$ signaling [97]. Increased TNF- $\alpha$ signaling leads the upregulation of inducible nitric oxide synthase (iNOS) which has also been implicated in IBD (reviewed in [98]). ADAM17 protein levels are increased in mucosal biopsies from patients with ulcerative colitis but not in Crohn's disease, indicating that it plays a pathogenic role in the former disease.

Neutralizing antibodies against TNF- $\alpha$ are effective in treating IBD [99]; however, antigenicity and high cost have raised interest in alternative strategies to block TNF- $\alpha$ signalling, such as inhibition of ADAM17.

Colon et al. showed that the colitis induced in rats by trinitrobenzene sulphonic acid (TNBS) is characterized by an increase in the levels of soluble TNF-alpha, ADAM17 and iNOS [100]. The ADAM17 inhibitor BB1101 blocked TNBS-induced increase in ADAM17 activity, TNF- $\alpha$ release and iNOS expression. Thus, inhibitors of ADAM17 may prove useful as a therapeutic means in IBD, in particular for patients suffering ulcerative colitis.

\section{Stroke}

Stroke, or cerebrovascular accident, often results in permanent disability and is the number two cause of mortality worldwide [101]. Moreover, the incidence of stroke is likely going to increase due to population ageing [102]. Stroke can be the result of either restricted/blocked bloodflow to part of the brain, or hemorhage, both resulting in neuronal necrosis. Despite the complexity and heterogeneity of the disease, accumulating evidence shows that inflammation plays a crucial role [103]. Thus, it is not surprising that TNF- $\alpha$, and therefore ADAM17, are considered therapeutic targets for the treatment of stroke. Confirming this notion, a selective small molecule inhibitor of ADAM17 (DPH-067517), suppresses ischemia-induced increase in soluble TNF- $\alpha$ and ameliorates ischemic stroke in rats [104]. Similarly, treatment of a rat model of reperfusion injury with the ADAM17 inhibitor Tissue Inhibitor of Metalloproteinase-3 (TIMP3) diminished the diseases severity compared with untreated rats [105].

\section{Other Inflammatory Diseases}

Aberrant ADAM17 expression is also connected to other inflammatory disorders such as peritonitis [106], polymyositis, dermatomyositis and inclusion body myositis [107]. In addition, ADAM17 protein levels were increased in gingival crevicular fluid taken from patients with periodontitis compared to that taken from healthy controls [108] and in placental tissue from pregnancies complicated by chorioamnionitis [109].

Blocking TNF- $\alpha$ signaling by using Etanercept is a current treatment for psoriasis. ELISA analysis on blood taken from psoriasis patients showed elevated ADAM17 protein expression [110] and treatment of a mouse model of epidermal hyperplasia with compound 1b, an MMP/ADAM17 inhibitor, led to a reduction in the severity of psoriasis in these mice [111].

Finally, increased ADAM17 expression is reported in blood vessels, macrophages and astrocytes in active lesions with evidence of recent myelin breakdown from MS patients [112].

\section{Cardiovascular Diseases}

Animal models suggest a role for ADAM17 in the development of the heart, likely through the cleavage of EGF-like ligands. For example, ADAM17 knockout mice show enlarged stenotic semilunar and atrioventricular heart valves suggestive of defective valvulogenesis [113]. Consistently, a number of cardiovascular disorders have been related to ADAM17 overexpression. Myocardial tissue from patients with myocarditis, hypertrophic obstructive cardiomyopathy and dilated cardiomyopathy displayed higher ADAM17 protein levels compared with healthy controls [114]. Likewise, ADAM17 protein expression was raised in arterial tissue from patients with atherosclerosis [115] and abdominal aortic aneurysm [116]. Peripheral Blood Mononuclear Cells taken from patients with heart failure also showed increased ADAM17 protein expression [116]. Finally, a positive correlation exists between elevated ADAM17 protein levels in aortic tissue biopsies and severity of acute myocardial infarction [117].

\section{Chronic Renal Diseases}

Independently of how they originate, most human kidney diseases are characterized by an initial damage, followed by progression of renal lesions developing towards complete parenchymal destruction and renal failure [118].

Although, the mechanisms of progression remains unclear Angiotensin II (AngII), seems to be involved since chronic AngII infusion leads to renal lesions in mice [119]. Genetic evidence indicates the participation of the EGFR pathway in the AngII-induced renal disease: mice overexpressing a dominant negative isoform of the EGFR are protected from these induced renal lesions [120]. Furthermore, AngII-induced lesions were substantially reduced in mice lacking TGF- $\alpha$ [120]. AngII causes induction and redistribution of ADAM17 to the apical membranes of distal renal tubules, where it is able to cleave the proTGF- $\alpha$ precursor so the soluble ligand can activate the receptor [120].

Pharmacologic inhibition of ADAM17 prevents renal deterioration, corroborating the role of the EGFR in the pathology of the disease and pointing to ADAM17 inhibitors as a new therapeutic strategy for preventing progression of chronic renal diseases [120].

\section{Respiratory Diseases}

ADAM17 expression is elevated in peripheral-blood monocytes from refractory asthma patients [121] and in the epithelial lining fluid of patients with pneumonia. Green and coworkers showed that ADAM17 has a role in regulating the local inflammatory response in community-acquired pneumonia through modulation of inflammatory cytokine levels [122].

ADAM17 protein is also overexpressed in the lungs of Wistar rats challenged with passive smoking and intratracheal instillation of LPS (a model for chronic obstructive pulmonary disorder, COPD). TNF- $\alpha$ and ErbB3 are known 
to be involved in the pathogenesis of COPD and so the contribution of ADAM17 to the disease seems to be two fold: through the activation of the TNF- $\alpha$ and ErbB3 pathways and, thus, inhibition of the metalloprotease seems to be a feasible therapeutic approach [123].

\section{Metabolic Diseases}

Compared to healty mice, diabetic mice heterozygous for the insulin receptor express lower levels of TIMP3, and inhibitor of ADAM17, and, consequently, higher ADAM17 activity. On the other hand, treatment with the ADAM17 inhibitor TAPI-1 causes an increase in insulin sensitivity and a decrease in hyperglycemia and vascular inflammation, suggesting that ADAM17 overactivity may cause diabetes and vascular inflammation [124]. Confirming this hypothesis, rats maintained on a fructose-rich diet for 6 weeks developed insulin resistance, but treatment with the ADAM17 inhibitor KB-R7785 reduced the severity of the disease [125].

ADAM17 also seems to be involved in diet-related diseases. Obesity caused by a high-fat diet in wild type mice leads to an increase in the expression of ADAM17 [126]. Heterozygous ADAM $17^{+/-}$mice fed a high fat diet were relatively protected from obesity and insulin-resistance compared to their wild-type littermates [127]. Increased ADAM17 expression is also detected in monocytes in response to LDL from diabetic patients versus controls [128]. Mice fed with a fat-free, high carbohydrate diet developed severe fatty liver infiltration. The severity of this condition was decreased upon treatment with the MMP inhibitor Marimastat, indication that ADAM17 is also involved in the pathogenesis of fatty liver [129].

\section{Alzheimer's Disease}

To our knowledge, the only pathology in which an increased ADAM17 activity has been suggested to be favourable is Alzheimer's disease.

The deposition of the $A \beta$ peptide in the brain is touted to play a causal role in the pathogenesis of the disease [130]. $\mathrm{A} \beta$ is generated from a transmembrane protein named APP through the cleavage by $\beta$ - and $\gamma$-secretases. Alternatively, APP may be cleaved by ADAM17 and ADAM10, which are also known as $\alpha$-secretases. The cleavage by ADAMs takes place within the region of APP that corresponds to A $\beta$ and, thus, prevents the generation of the amiloidogenic peptide.

The feasibility of a therapeutic strategy based on the activation of metalloproteinases with alpha-secretase activity has been proven in animal models. The overexpression of functional ADAM10 in neurons of transgenic mice also overexpressing human APP leads to increased production of APPs $\alpha$ (the soluble $\alpha$-secretase shedded APP fragment) and reduced amyloid plaque formation and overall cognitive deficits [131]. Similarly, it has been proposed that the upregulation of ADAM17 is a promising therapeutic approach for treating Alzheimer's disease [132].

\section{Other Diseases}

ADAM17 protein overexpression is also linked with a variety of diseases not falling into the above categories.
ADAM17 was elevated in endometriosis tissue compared to healthy endometrium [133]. ADAM17 is overexpressed at the site of injury of the sciatic nerve in a rat model of sciatic neuropathy as shown by immunohistochemistry [134]. Western blot detected an increase in ADAM17 protein expression in the brain cortex of rats subjected to immobilization stress [135]. Overexpression of ADAM17 protein was also detected in Peripheral Blood Mononuclear Cells from patients with systemic scleroderma [136] and in sural nerve biopsies of patients suffering from Guillain-Barre syndrome [137]. In addition, immunohistochemical analysis of nerve biopsies from leprosy patients showed an increase in ADAM17 protein expression compared with normal tissue [138].

Inhibition of ADAM17 also indicates its participation in additional diseases. Treatment with the ADAM17 inhibitor BB3103 protected rats against mucosal injury induced by aspirin administration which is used as a model for peptic ulcer [139]. Similarly, in a rat model for pneumococcal meningitis, disease severity was reduced by treating with the ADAM10/ADAM17 inhibitor BB1101 [140]. Finally, a role for ADAM17 in wound healing was suggested by a scratchwound model in human NCI-H292 human airway epithelial cells as the cells exhibited impaired wound repair when ADAM17 was suppressed by RNAi [141].

\section{BLOCKING ADAM17}

Leaving aside Alzheimer's disease, the unusualy high number of diseases in which the overactivation of ADAM17 has been suggested to play a role underscores the immense therapeutic potential of inhibitors. The availability of the structure of the proteolytic domain of ADAM17 [142] at a resolution of $1.7 \AA$, has allowed the development of numerous inhibitors (Table 2) with various degrees of specificity. Some compounds block, in addition to ADAM17, closely related ADAMs and MMPs, while other seem to be highly specific. ADAM17 inhibitors are being assayed in different preclinical models of different diseases as well as in clinical trials, discussed below.

\section{Rheumatoid Arthritis}

Initially, the lack of specificifity of metalloproteinase inhibitors was not considered a drawback. Since various MMPs contribute to joint destruction, in principle, ADAM17 inhibitors with additional activity against MMPs could provide an advantage for the treatment of RA. Phase II clinical trials for RA with TMI-005 (Apratastat) was conducted based on this hypothesis. However, this inhibitor showed low efficacy (Apratastat) or undesired side effects, likely due to the inhibition of multiple proteases. BMS-561392, an ADAM17 specific inhibitor demonstrated hepatotoxicity. This toxicity was thought to occur due to specific blocking of TNFR release by ADAM17, possibly posing a universal problem when inhibiting ADAM17 [91]. GI5402, a general metalloproteinase inhibitor that targets ADAM17, moderated the release of plasma-soluble TNF- $\alpha$ after intravenous injection of LPS in healthy individuals without producing the unwanted pro-inflammatory responses observed in in vitro experiments [143]. In view of these results, highly selective ADAM17 inhibitors are being developed to assure better 
Table 2. Synthetic ADAM17 Inhibitors

\begin{tabular}{|c|c|c|c|c|c|}
\hline Inhibitor & Target & Stage of Development & Disease Treatment & Developed by & Reference \\
\hline $\begin{array}{c}\text { Analogues } 14,15 \\
\text { and } 27\end{array}$ & ADAM17 & Preclinical & & Wyeth & {$[147]$} \\
\hline BB-94 (batimastat) & MMPs & Discontinued & & British Biotech & {$[190]$} \\
\hline BB1101 & MMPs & Preclinical & & AstraZeneca & {$[191]$} \\
\hline BB3103 & ADAM17/ADAM10 & Preclinical & & $\begin{array}{l}\text { British Biotech } \\
\text { Pharmaceuticals }\end{array}$ & [192] \\
\hline $\begin{array}{l}\text { BMS-561392 } \\
\text { (DPC-333) }\end{array}$ & ADAM17 & Phase 1 Discontinued & RA & Bristol-Myers Squibb & [193] \\
\hline BMS-566394 & ADAM17 & Preclinical & & Bristol-Myers Squibb & [91] \\
\hline CH-138 & $\begin{array}{c}\text { ADAM17, } \\
\text { Proteases, MMPs }\end{array}$ & Discontinued & & $\mathrm{UCB}$ & [91] \\
\hline Compound 2o & ADAM17 & Preclinical & & Bristol-Myers Squibb & {$[148]$} \\
\hline Compound 4d & ADAM17 & Preclinical & & Nippon Organon & [194] \\
\hline Compound $4 \mathrm{t}$ & ADAM17 & Preclinical & & Wyeth & {$[195]$} \\
\hline Compound 51 & ADAM17 & Preclinical & & Dupont Pharmaceuticals & {$[196]$} \\
\hline Compound $5 \mathrm{~h}$ and $5 \mathrm{i}$ & ADAM17 & Preclinical & & Pfizer & [197] \\
\hline Compound $5 \mathrm{j}$ & ADAM17 & Preclinical & & Wyeth & [198] \\
\hline Compound 51 & ADAM17 & Preclinical & & Bristol-Myers Squibb & [199] \\
\hline Compound 60 & ADAM17 & Preclinical & & Wakunaga Pharmaceutical & {$[200]$} \\
\hline Compound 7d & ADAM17 & Preclinical & & Bristol-Myers Squibb, & {$[201]$} \\
\hline $\begin{array}{l}\text { Compound 7e, } \\
\text { Cyclic Ether } 50\end{array}$ & ADAM17 & Preclinical & & Abbott & {$[202]$} \\
\hline Compound 8b & ADAM17 & Preclinical & & Vertex & {$[146]$} \\
\hline $\begin{array}{c}\text { Compounds } 11,12 \text {, } \\
15 \mathrm{a}-\mathrm{b}, 18\end{array}$ & ADAM17 & Preclinical & & Kaken Pharmaceutical & {$[203]$} \\
\hline Compounds 41, 32, 62 & ADAM17 & Preclinical & & Bristol-Myers Squibb & {$[204]$} \\
\hline Compounds 64 and 65 & ADAM17 & Preclinical & & Wyeth & {$[205]$} \\
\hline CP-661,631 & & Preclinical & & Pfizer & {$[206]$} \\
\hline $\begin{array}{l}\text { Derivative } 7 \mathrm{~b}, \\
\text { Compound } 59\end{array}$ & ADAM17 & Preclinical & & Nippon Organon & {$[200]$} \\
\hline DPC-A38088 & ADAM17 & Preclinical & & Bristol-Myers Squibb & $\begin{array}{c}\text { http: } \\
\text { //oasys2.confex.com/a } \\
\text { cs/228nm/techprogram } \\
\text { /P749069.HTM; [91] }\end{array}$ \\
\hline DPH-067517 & ADAM17 & Preclinical & & Bristol-Myers Squibb & [207] \\
\hline $\begin{array}{c}\text { GI5402 (GI-245402, } \\
\text { BB-2983) }\end{array}$ & ADAM17, MMPs & Phase I, Discontinued & RA & Glaxo Smithkline & {$[143]$} \\
\hline GM6001 & ADAM17, MMPs & & & Chemicon & {$[208]$} \\
\hline GW-3333 & ADAM17, MMPs & $\begin{array}{c}\text { Preclinical } \\
\text { Discontinued }\end{array}$ & & GlaxoSmithKline & [209] \\
\hline GW280264X & ADAM17/ADAM10 & Preclinical & & GlaxoSmithKline & [210] \\
\hline
\end{tabular}


(Table 2) contd....

\begin{tabular}{|c|c|c|c|c|c|}
\hline Inhibitor & Target & Stage of Development & Disease Treatment & Developed by & Reference \\
\hline GW4459 & ADAM17 & Discontinued & & Glaxo Smithkline & {$[211]$} \\
\hline IK682 & ADAM17 & Preclinical & & Bristol-Myers Squibb & [212] \\
\hline IM491 & ADAM17 & Preclinical & & Bristol-Myers Squibb & {$[213]$} \\
\hline INCB3619 & $\begin{array}{c}\text { ADAM17, } \\
\text { ADA10, MMPs }\end{array}$ & Preclinical & NSCLC & Incyte & {$[72,82]$} \\
\hline INCB4298 & ADAM17 & Preclinical & & Incyte & {$[72]$} \\
\hline INCB7839 & ADAM10, ADAM17 & Phase II & Breast cancer & Incyte & {$[214]$} \\
\hline KB-R7785 & $\begin{array}{c}\text { ADAM17, } \\
\text { ADAM12, MMPs }\end{array}$ & Preclinical & & Nippon Organon & {$[191]$} \\
\hline $\begin{array}{l}\text { PKF242-484/ } \\
\text { PKF241-466 }\end{array}$ & ADAM17, MMPs & Preclinical & & Novartis & {$[215,216]$} \\
\hline R-618 & ADAM17 & Phase I Discontinued & & Hoffmann-La Roche & [91] \\
\hline Ro 32-7315 & & Preclinical & & Roche & {$[217]$} \\
\hline TAPI-1 & $\begin{array}{c}\text { ADAM17, } \\
\text { ADAMs MMPs }\end{array}$ & Preclinical & & $\begin{array}{l}\text { Peptides International, } \\
\text { Merck Biosciences, } \\
\text { BIOMOL }\end{array}$ & {$[218]$} \\
\hline TAPI-2 & $\begin{array}{c}\text { ADAM17, } \\
\text { ADAMs, MMPs }\end{array}$ & Preclinical & & $\begin{array}{c}\text { Peptides International, } \\
\text { Merck Biosciences, } \\
\text { BIOMOL }\end{array}$ & {$[219-221]$} \\
\hline TMI-005 (Apratastat) & ADAM17, MMPs & Phase II Discontinued & RA & Wyeth & {$[222]$} \\
\hline TMI-1 & ADAM17, MMPs & Preclinical & RA & Wyeth & {$[223]$} \\
\hline TMI-2 & ADAM17 & Preclinical & & Wyeth & {$[224]$} \\
\hline W-3646 & ADAM17 & Discontinued & & Wakanuga Pharmaceutical & [91] \\
\hline WTACE2 & ADAM17 & Preclinical & $\begin{array}{c}\text { Polycystic kidney } \\
\text { disease }\end{array}$ & Wyeth & {$[225]$} \\
\hline XL784 & $\begin{array}{c}\text { ADAM10/ } \\
\text { ADAM17/MMPs }\end{array}$ & Phase II Discontinued & $\begin{array}{c}\text { Diabetic } \\
\text { Nephro-pathy }\end{array}$ & Exelixis & $\begin{array}{c}\text { [226] http: } \\
\text { //www.exelixis.com/pi } \\
\text { peline_xl784.shtml\#cd }\end{array}$ \\
\hline
\end{tabular}

efficacy and less side-effects for the treatment of RA and other diseases where overactivation of ADAM17 plays a role.

\section{Renal Diseases}

The ADAM10/ADAM17/MMP inhibitor XL784, designed to circumvent MMP1-associated musculoskeletal toxicity was well-tolerated in a Phase II clinical trial for diabetic nephropathy (NCT00312780). Unfortunately, the trial did not meet its primary endpoint of reducing proteinuria.

\section{Cancer}

The failure of several metalloproteinase inhibitors with different levels of specificity (Table 2) in clinical trials led to the questioning of metalloproteases as therapeutic targets in cancer [144] and the subsequent realization that inhibition of certain metalloproteinases may in fact promote tumor progression [145]. Foreseeably, and taking into consideration the effectiveness of ADAM17 blockade in preclinical assays [72], the clinical efficacy of more selective metalloproteinase inhibitors will be tested in the future. Non-hydroxamate inhibitors include the thiol-based "compound $8 b$ " [146], the pyrimidinetrione "compound 51" [147] and the hydroxyacetamide "compound 20" [148]. In preclinical models INCB7839 showed single agent efficacy and synergism with other EGFR therapies and chemotherapy [149]. A Phase II trial in HER2 positive breast cancer has begun with INCB7839 and will be used to determine the its effectiveness in combination with Herceptin.

\section{Provisional Conclusions on the Use of Inhibitors}

Several inhibitors of ADAM17 have failed during clinical trials because lack of efficacy and/or toxicity. The main 
stumbling block in the further development of ADAM17 inhibitors is the observation that promising in vitro nanomolar range inhibitors do not always show efficacy in vivo. This is not unique for ADAM17 inhibitors but rather a universal problem in the development of therapeutic compounds. The gap between in vitro and in vivo is due in part to pharmacokinetic factors coming into play when considering the whole organism and an incomplete understanding of the biology of ADAM17 inhibition. In addition, frequently molecules unrelated to the target, present in the plasma, are able to interfere with the inhibitory mechanism itself. Regarding toxicity, there is a clear need of more specific ADAM17 inhibitors. Higher specificity should help to diminish possible side effects and allow higher doses to be administered. Because of the observed toxicity effects in clinical trials, ADAM17 inhibitors are predicted to be of best use in cancer treatment. Since known and possible new undesirable effects, are more tolerated in view of a relatively short life cancer treatment in contrast to permanent RA care. The requirement of ADAM17 during EGFR activation, wich is a validated anti-cancer target, further advocates this possibility.

\section{ACKNOWLEDGEMENTS}

The research in our laboratory is supported by grants from the Instituto de Salud Carlos III (Intrasalud PI081154 and the network of cooperative cancer research (RTICC)), the Breast Cancer Research Foundation (BCRF), Fundación Mutua Madrileña and La Marató de TV3, to JA. CE holds a Juan de la Cierva post-doctoral fellowship.

\section{ABBREVIATIONS}

$\begin{array}{ll}\text { TACE } & \text { Tumor necrosis factor- } \alpha \text { Converting } \\ \text { ADAM } & =\text { A Disintegrin and A Metalloproteinase } \\ \text { MMP } & \text { Matrix Metalloproteinase } \\ \text { (pro-)TNF- } \alpha & =\text { (pro-)Tumor Necrosis Factor- } \alpha \\ \text { PKC } & =\text { Protein Kinase C } \\ \text { ERK } & =\text { Extracellular signal-Regulated Kinase } \\ \text { MAD2 } & =\text { Mitotic Arrest Deficient } 2 \\ \text { PDZ } & =\text { post synaptic density protein (PSD95), } \\ & \text { Drosophila disc large tumor suppressor } \\ & \text { (DlgA), and zonula occludens-1 protein } \\ \text { TGF- } \alpha & =\text { Transforming Growth Factor- } \alpha \\ \text { EGF(R) } & =\text { Epidermal Growth Factor (Receptor) } \\ \text { RIP } & =\text { Regulated Intramembrane Proteolysis } \\ \text { ICD } & =\text { IntraCellular Domain } \\ \text { APP } & =\text { Amyloid Precursor Protein } \\ \text { RA } & =\text { rheumatoid arthritis } \\ \text { IBD } & =\text { Inflammatory Bowel Disease } \\ \text { MS } & =\text { Multiple Sclerosis } \\ \text { A } \beta & \text { Amyloid } \beta\end{array}$
NSCLC
$=$ Non-Small-Cell Lung Cancer
HIF
LPS
$=$ Hypoxia Inducible Factor
AIA
$=$ LipoPolySaccharides
CIA
$=$ Adjuvant-Induced Arthritis
iNOS
$=$ Collagen-Induced Arthritis
TNBS
$=$ inducible Nitric Oxide Synthase
TIMP
$=$ TriNitroBenzene Sulphonic acid
AngII
COPD
$=$ Tissue Inhibitor of Metalloproteinase
$=$ Angiotensin II
$=$ Chronic Obstructive Pulmonary Disorder

\section{REFERENCES}

[1] Seals DF, Courtneidge SA. The ADAMs family of metalloproteases: multidomain proteins with multiple functions. Genes Dev 2003; 17(1): 7-30.

[2] Milla ME, Gonzales PE, Leonard JD. The TACE zymogen: reexamining the role of the cysteine switch. Cell Biochem Biophys 2006; 44(3): 342-8.

[3] Borroto A, Ruiz-Paz S, Villanueva de la Torre T, Borrell-Pages M, Merlos-Suarez A, Pandiella A, et al. Impaired trafficking and activation of TACE in cell mutants defective in protein ectodomain shedding. J Biol Chem 2003; 278: 25933-9.

[4] Endres K, Anders A, Kojro E, Gilbert S, Fahrenholz F, Postina R. Tumor necrosis factor-alpha converting enzyme is processed by proprotein-convertases to its mature form which is degraded upon phorbol ester stimulation. Eur J Biochem 2003; 270(11): 2386-93.

[5] Esselens CW, Malapeira J, Colome N, Moss M, Canals F, Arribas J. Metastasis-associated C4.4A, a GPI-anchored protein cleaved by ADAM10 and ADAM17. Biol Chem 2008; 389(8): 1075-84.

[6] Gonzales PE, Solomon A, Miller AB, Leesnitzer MA, Sagi I, Milla ME. Inhibition of the tumor necrosis factor-alpha-converting enzyme by its pro domain. J Biol Chem 2004; 279(30): 31638-45.

[7] Moss ML, Bomar M, Liu Q, Sage H, Dempsey P, Lenhart PM, et $a l$. The ADAM10 prodomain is a specific inhibitor of ADAM10 proteolytic activity and inhibits cellular shedding events. J Biol Chem 2007; 282(49): 35712-21.

[8] Blobel CP. ADAMs: key components in EGFR signalling and development. Nat Rev Mol Cell Biol 2005; 6(1): 32-43.

[9] Bode W, Grams F, Reinemer P, Gomis-Ruth FX, Baumann U, McKay DB, et al. The metzincin-superfamily of zinc-peptidases. Adv Exp Med Biol 1996; 389: 1-11.

[10] Peschon JJ, Slack JL, Reddy P, Stocking KL, Sunnarborg SW, Lee $\mathrm{DC}$, et al. An essential role for ectodomain shedding in mammalian development. Science 1998; 282(5392): 1281-4.

[11] Horiuchi K, Kimura T, Miyamoto T, Takaishi H, Okada Y, Toyama $\mathrm{Y}$, et al. Cutting edge: TNF-alpha-converting enzyme (TACE/ADAM17) inactivation in mouse myeloid cells prevents lethality from endotoxin shock. J Immunol 2007; 179(5): 2686-9.

[12] Althoff K, Müllberg J, Aasland D, Voltz N, Kallen K, Grotzinger J, et al. Recognition sequences and structural elements contribute to shedding susceptibility of membrane proteins. Biochem J 2001; 353: 663-72.

[13] Brakebusch C, Varfolomeev EE, Batkin M, Wallach D. Structural requirements for inducible shedding of the p55 tumor necrosis factor receptor. J Biol Chem 1994; 269: 32488-96.

[14] Migaki GI, Kahn J, Kishimoto TK. Mutational analysis of the membrane-proximal cleavage site of L-selectin: relaxed sequence specificity surrounding the cleavage site. J Exp Med 1995; 182: 549-57.

[15] Arribas J, López-Casillas F, Massagué J. Role of the Juxtamembrane Domains of the Transforming Growth Factor- $\alpha$ Precursor and the $\beta$-Amyloid Precursor Protein in Regulated Ectodomain Shedding. J Biol Chem 1997; 272: 17160-5.

[16] Lambert DW, Yarski M, Warner FJ, Thornhill P, Parkin ET, Smith $\mathrm{AI}$, et al. Tumor necrosis factor-alpha convertase (ADAM17) mediates regulated ectodomain shedding of the severe-acute respiratory syndrome-coronavirus (SARS-CoV) receptor, angiotensin- 
converting enzyme-2 (ACE2). J Biol Chem 2005; 280(34): 301139.

[17] Black RA, Doedens JR, Mahimkar R, Johnson R, Guo L, Wallace $\mathrm{A}$, et al. Substrate specificity and inducibility of TACE (tumour necrosis factor alpha-converting enzyme) revisited: the Ala-Val preference, and induced intrinsic activity. Biochem Soc Symp 2003; (70): 39-52.

[18] Tang P, Hung MC, Klostergaard J. Length of the linking domain of human pro-tumor necrosis factor determines the cleavage processing. Biochemistry 1996; 35(25): 8226-33.

[19] White JM. ADAMs: modulators of cell-cell and cell-matrix interactions. Curr Opin Cell Biol 2003; 15(5): 598-606.

[20] Guo W, Giancotti FG. Integrin signalling during tumour progression. Nat Rev Mol Cell Biol 2004; 5(10): 816-26.

[21] Ridley AJ, Schwartz MA, Burridge K, Firtel RA, Ginsberg MH, Borisy $\mathrm{G}$, et al. Cell migration: integrating signals from front to back. Science 2003; 302(5651): 1704-9.

[22] Arribas J, Bech-Serra JJ, Santiago-Josefat B. ADAMs, cell migration and cancer. Cancer Metastasis Rev 2006; 25(1): 57-68.

[23] Huang J, Bridges LC, White JM. Selective modulation of integrinmediated cell migration by distinct ADAM family members. Mol Biol Cell 2005; 16(10): 4982-91.

[24] Reddy P, Slack JL, Davis R, Cerretti DP, Kozlosky CJ, Blanton $\mathrm{RA}$, et al. Functional analysis of the domain structure of tumor necrosis factor-alpha converting enzyme. J Biol Chem 2000; 275(19): 14608-14.

[25] Milla ME, Leesnitzer MA, L. MM, Clay WC, Carter HL, Miller $\mathrm{AB}$, et al. Specific sequence elements are required for the expression of functional tumor necrosis factor-alpha-converting enzyme (TACE). J Biol Chem 1999; 274: 30563-70.

[26] Wang Y, Herrera AH, Li Y, Belani KK, Walcheck B. Regulation of mature ADAM17 by redox agents for L-selectin shedding. J Immunol 2009; 182(4): 2449-57

[27] Janes PW, Saha N, Barton WA, Kolev MV, Wimmer-Kleikamp $\mathrm{SH}$, Nievergall E, et al. Adam meets Eph: an ADAM substrate recognition module acts as a molecular switch for ephrin cleavage in trans. Cell 2005; 123(2): 291-304.

[28] Pasquale EB. Eph-ephrin bidirectional signaling in physiology and disease. Cell 2008; 133(1): 38-52.

[29] Hattori M, Osterfield M, Flanagan JG. Regulated Cleavage of a Contact-Mediated Axon Repellent. Science 2000; 289: 1360-5.

[30] Villanueva de la Torre T, Bech-Serra JJ, Ruiz-Paz S, Baselga J, Arribas J. Inactivating mutations block the tumor necrosis factoralpha-converting enzyme in the early secretory pathway. Biochem Biophys Res Commun 2004; 314(4): 1028-35.

[31] Wild-Bode C, Fellerer K, Kugler J, Haass C, Capell A. A basolateral sorting signal directs ADAM10 to adherens junctions and is required for its function in cell migration. J Biol Chem 2006; 281(33): 23824-9.

[32] Marcello E, Gardoni F, Mauceri D, Romorini S, Jeromin A, Epis R, et al. Synapse-associated protein-97 mediates alpha-secretase ADAM10 trafficking and promotes its activity. J Neurosci 2007; 27(7): 1682-91.

[33] Peiretti F, Deprez-Beauclair P, Bonardo B, Aubert H, Juhan-Vague I, Nalbone G. Identification of SAP97 as an intracellular binding partner of TACE. J Cell Sci 2003; 116(Pt 10): 1949-57.

[34] Black RA. Tumor necrosis factor-alpha converting enzyme. Int J Biochem Cell Biol 2002; 34(1): 1-5.

[35] Lee DC, Sunnarborg SW, Hinkle CL, Myers TJ, Stevenson MY, Russell WE, et al. TACE/ADAM17 processing of EGFR ligands indicates a role as a physiological convertase. Ann N Y Acad Sci 2003; 995: 22-38

[36] Borrell-Pages M, Rojo F, Albanell J, Baselga J, Arribas J. TACE is required for the activation of the EGFR by TGF-alpha in tumors. Embo J 2003; 22(5): 1114-24.

[37] Aggarwal BB. Signalling pathways of the TNF superfamily: a double-edged sword. Nat Rev Immunol 2003; 3(9): 745-56.

[38] Grell M, Douni E, Wajant H, Lohden M, Clauss M, Maxeiner B, et al. The transmembrane form of tumor necrosis factor is the prime activating ligand of the $80 \mathrm{kDa}$ tumor necrosis factor receptor. Cell 1995; 83(5): 793-802.

[39] Mueller C, Corazza N, Trachsel-Loseth S, Eugster HP, BuhlerJungo M, Brunner T, et al. Noncleavable transmembrane mouse tumor necrosis factor-alpha (TNFalpha) mediates effects distinct from those of wild-type TNFalpha in vitro and in vivo. J Biol Chem 1999; 274(53): 38112-8.
[40] Montero JC, Yuste L, Diaz-Rodriguez E, Esparis-Ogando A, Pandiella A. Differential shedding of transmembrane neuregulin isoforms by the tumor necrosis factor-alpha-converting enzyme. Mol Cell Neurosci 2000; 16: 631-48.

[41] Fortini ME. Notch and presenilin: a proteolytic mechanism emerges. Curr Opin Cell Biol 2001; 13: 627-34.

[42] Selkoe D, Kopan R. Notch and Presenilin: regulated intramembrane proteolysis links development and degeneration. Annu Rev Neurosci 2003; 26: 565-97.

[43] Linggi B, Carpenter G. ErbB-4 s80 intracellular domain abrogates ETO2-dependent transcriptional repression. J Biol Chem 2006; 281(35): 25373-80.

[44] Reiss K, Maretzky T, Ludwig A, Tousseyn T, de Strooper B, Hartmann D, et al. ADAM10 cleavage of N-cadherin and regulation of cell-cell adhesion and beta-catenin nuclear signalling. Embo J 2005; 24(4): 742-52.

[45] Okamoto I, Kawano Y, Muramaki D, Sasayama T, Araki N, Miki $\mathrm{T}$, et al. Proteolytic release of CD44 intracellular domain and its role in the CD44 signaling pathway. J Cell Biol 2001; 26: 755-62.

[46] Bech-Serra JJ, Santiago-Josefat B, Esselens C, Saftig P, Baselga J, Arribas $\mathrm{J}$, et al. Proteomic identification of desmoglein 2 and activated leukocyte cell adhesion molecule as substrates of ADAM17 and ADAM10 by difference gel electrophoresis. Mol Cell Biol 2006; 26(13): 5086-95.

[47] Fabre-Lafay S, Garrido-Urbani S, Reymond N, Goncalves A, Dubreuil P, Lopez M. Nectin-4, a new serological breast cancer marker, is a substrate for tumor necrosis factor-alpha-converting enzyme (TACE)/ADAM-17. J Biol Chem 2005; 280(20): 19543 50.

[48] Franzke CW, Tasanen K, Schacke H, Zhou Z, Tryggvason K, Mauch C, et al. Transmembrane collagen XVII, an epithelial adhesion protein, is shed from the cell surface by ADAMs. Embo J 2002; 21(19): 5026-35.

[49] Garton KJ, Gough PJ, Philalay J, Wille PT, Blobel CP, Whitehead $\mathrm{RH}$, et al. Stimulated shedding of vascular cell adhesion molecule 1 (VCAM-1) is mediated by tumor necrosis factor-alpha-converting enzyme (ADAM 17). J Biol Chem 2003; 278(39): 37459-64.

[50] Stoeck A, Keller S, Riedle S, Sanderson MP, Runz S, Le Naour F, et al. A role for exosomes in the constitutive and stimulus-induced ectodomain cleavage of L1 and CD44. Biochem J 2006; 393(Pt 3): 609-18.

[51] Tsakadze NL, Sithu SD, Sen U, English WR, Murphy G, D'Souza SE. Tumor necrosis factor-alpha-converting enzyme (TACE/ ADAM-17) mediates the ectodomain cleavage of intercellular adhesion molecule-1 (ICAM-1). J Biol Chem 2006; 281(6): 3157-64.

[52] Nagano O, Saya H. Mechanism and biological significance of CD44 cleavage. Cancer Sci 2004; 95(12): 930-5.

[53] Brennan FM, Maini RN, Feldmann M. TNF alpha--a pivotal role in rheumatoid arthritis? Br J Rheumatol 1992; 31(5): 293-8.

[54] Martel-Pelletier J, Alaaeddine N, Pelletier JP. Cytokines and their role in the pathophysiology of osteoarthritis. Front Biosci 1999; 4: D694-703.

[55] Stokkers PC, Camoglio L, van Deventer SJ. Tumor necrosis factor (TNF) in inflammatory bowel disease: gene polymorphisms, animal models, and potential for anti-TNF therapy. J Inflamm 1995; 47(1-2): 97-103.

[56] Hallenbeck JM. The many faces of tumor necrosis factor in stroke. Nat Med 2002; 8(12): 1363-8.

[57] Beutler B, Cerami A. Cachectin/tumor necrosis factor: an endogenous mediator of shock and inflammation. Immunol Res 1986; 5(4): 281-93.

[58] Navikas V, Link H. Review: cytokines and the pathogenesis of multiple sclerosis. J Neurosci Res 1996; 45(4): 322-33.

[59] Haro H, Crawford HC, Fingleton B, Shinomiya K, Spengler DM, Matrisian LM. Matrix metalloproteinase-7-dependent release of tumor necrosis factor-alpha in a model of herniated disc resorption. J Clin Invest 2000; 105(2): 143-50.

[60] Rosendahl MS, Ko SC, Long DL, Brewer MT, Rosenzweig B, Hedl E, et al. Identification and characterization of a pro-tumor necrosis factor-alpha-processing enzyme from the ADAM family of zinc metalloproteases. J Biol Chem 1997; 272(39): 24588-93.

[61] Zheng Y, Saftig P, Hartmann D, Blobel C. Evaluation of the contribution of different ADAMs to tumor necrosis factor alpha (TNFalpha) shedding and of the function of the TNFalpha ectodomain in ensuring selective stimulated shedding by the TNFalpha 
convertase (TACE/ADAM17). J Biol Chem 2004; 279(41): 42898906.

[62] Black RA, Rauch CT, Kozlosky CJ, Peschon JJ, Slack JL, Wolfson $\mathrm{MF}$, et al. A metalloproteinase disintegrin that releases tumournecrosis factor-alpha from cells. Nature 1997; 385(6618): 729-33.

[63] Selkoe DJ. Defining molecular targets to prevent Alzheimer disease. Arch Neurol 2005; 62(2): 192-5.

[64] Selkoe DJ, Schenk D. Alzheimer's disease: molecular understanding predicts amyloid-based therapeutics. Annu Rev Pharmacol Toxicol 2003; 43: 545-84.

[65] Buxbaum JD, Liu KN, Luo Y, Slack JL, Stocking KL, Peschon JJ, et al. Evidence that tumor necrosis factor alpha converting enzyme is involved in regulated alpha-secretase cleavage of the Alzheimer amyloid protein precursor. J Biol Chem 1998; 273: 27765-7.

[66] Merlos-Suárez A, Fernández -Larrea J, Reddy P, Baselga J, Arribas $\mathrm{J}$. proTNF- $\alpha$ processing activity is tightly controlled by a component that does not affect Notch processing. J Biol Chem 1998; 273: 24955-62.

[67] Vardy ER, Hussain I, Hooper NM. Emerging therapeutics for Alzheimer's disease. Expert Rev Neurother 2006; 6(5): 695-704.

[68] Yarden Y, Sliwkowski MX. Untangling the ErbB signalling network. Nat Rev Mol Cell Biol 2001; 2(2): 127-37.

[69] Baselga J, Albanell J, Molina MA, Arribas J. Mechanism of action of trastuzumab and scientific update. Semin Oncol 2001; 28 (5 Suppl 16): 4-11.

[70] Blackhall F, Ranson M, Thatcher N. Where next for gefitinib in patients with lung cancer? Lancet Oncol 2006; 7(6): 499-507.

[71] Gatzemeier U, Groth G, Butts C, Van Zandwijk N, Shepherd F, Ardizzoni A, et al. Randomized phase II trial of gemcitabinecisplatin with or without trastuzumab in HER2-positive non-smallcell lung cancer. Ann Oncol 2004; 15(1): 19-27.

[72] Zhou BB, Peyton M, He B, Liu C, Girard L, Caudler E, et al. Targeting ADAM-mediated ligand cleavage to inhibit HER3 and EGFR pathways in non-small cell lung cancer. Cancer Cell 2006; 10(1): 39-50.

[73] Baselga J. Targeting the epidermal growth factor receptor: a clinical reality. J Clin Oncol 2001; 19: 41S-4S.

[74] McGowan PM, Ryan BM, Hill AD, McDermott E, O'Higgins N, Duffy MJ. ADAM-17 expression in breast cancer correlates with variables of tumor progression. Clin Cancer Res 2007; 13(8): 233543.

[75] Santiago-Josefat B, Esselens C, Bech-Serra JJ, Arribas J. Posttranscriptional up-regulation of ADAM17 upon epidermal growth factor receptor activation and in breast tumors. J Biol Chem 2007; 282(11): 8325-31.

[76] Kenny PA, Bissell MJ. Targeting TACE-dependent EGFR ligand shedding in breast cancer. J Clin Invest 2007; 117(2): 337-45.

[77] Merchant NB, Voskresensky I, Rogers CM, Lafleur B, Dempsey PJ, Graves-Deal R, et al. TACE/ADAM-17: a component of the epidermal growth factor receptor axis and a promising therapeutic target in colorectal cancer. Clin Cancer Res 2008; 14(4): 1182-91.

[78] Ringel J, Jesnowski R, Moniaux N, Luttges J, Choudhury A, Batra $\mathrm{SK}$, et al. Aberrant expression of a disintegrin and metalloproteinase 17/tumor necrosis factor-alpha converting enzyme increases the malignant potential in human pancreatic ductal adenocarcinoma. Cancer Res 2006; 66(18): 9045-53.

[79] Karan D, Lin FC, Bryan M, Ringel J, Moniaux N, Lin MF, et al. Expression of ADAMs (a disintegrin and metalloproteases) and TIMP-3 (tissue inhibitor of metalloproteinase-3) in human prostatic adenocarcinomas. Int J Oncol 2003; 23(5): 1365-71.

[80] Tanaka Y, Miyamoto S, Suzuki SO, Oki E, Yagi H, Sonoda K, et $a l$. Clinical significance of heparin-binding epidermal growth factor-like growth factor and a disintegrin and metalloprotease 17 expression in human ovarian cancer. Clin Cancer Res 2005; 11(13): 4783-92.

[81] Takamune Y, Ikebe T, Nagano O, Nakayama H, Ota K, Obayashi $\mathrm{T}$, et al. ADAM-17 associated with CD44 cleavage and metastasis in oral squamous cell carcinoma. Virchows Arch 2007; 450(2): 169-77.

[82] Fridman JS, Caulder E, Hansbury M, Liu X, Yang G, Wang Q, et al. Selective inhibition of ADAM metalloproteases as a novel approach for modulating ErbB pathways in cancer. Clin Cancer Res 2007; 13(6): 1892-902.

[83] Franovic A, Robert I, Smith K, Kurban G, Pause A, Gunaratnam L, et al. Multiple Acquired Renal Carcinoma Tumor Capabilities
Abolished upon Silencing of ADAM17. Cancer Res 2006; 66(16): 8083-90.

[84] Zheng X, Jiang F, Katakowski M, Kalkanis SN, Hong X, Zhang X, et al. Inhibition of ADAM17 reduces hypoxia-induced brain tumor cell invasiveness. Cancer Sci 2007; 98(5): 674-84.

[85] Abdel-Nasser AM, Rasker JJ, Valkenburg HA. Epidemiological and clinical aspects relating to the variability of rheumatoid arthritis. Semin Arthritis Rheum 1997; 27(2): 123-40.

[86] Majithia V, Geraci SA. Rheumatoid arthritis: diagnosis and management. Am J Med 2007; 120(11): 936-9.

[87] Firestein GS. Evolving concepts of rheumatoid arthritis. Nature 2003; 423(6937): 356-61.

[88] Patel IR, Attur MG, Patel RN, Stuchin SA, Abagyan RA, Abramson SB, et al. TNF-alpha convertase enzyme from human arthritisaffected cartilage: isolation of cDNA by differential display, expression of the active enzyme, and regulation of TNF-alpha. J Immunol 1998; 160(9): 4570-9.

[89] Charbonneau M, Harper K, Grondin F, Pelmus M, McDonald PP, Dubois CM. Hypoxia-inducible factor mediates hypoxic and tumor necrosis factor alpha-induced increases in tumor necrosis factoralpha converting enzyme/ADAM17 expression by synovial cells. J Biol Chem 2007; 282(46): 33714-24.

[90] Moreland LW, Baumgartner SW, Schiff MH, Tindall EA, Fleischmann RM, Weaver AL, et al. Treatment of rheumatoid arthritis with a recombinant human tumor necrosis factor receptor (p75)-Fc fusion protein. N Engl J Med 1997; 337(3): 141-7.

[91] Moss ML, Sklair-Tavron L, Nudelman R. Drug insight: tumor necrosis factor-converting enzyme as a pharmaceutical target for rheumatoid arthritis. Nat Clin Pract Rheumatol 2008; 4(6): 300-9.

[92] Newton RC, Solomon KA, Covington MB, Decicco CP, Haley PJ, Friedman SM, et al. Biology of TACE inhibition. Ann Rheum Dis 2001; 60 Suppl 3: iii25-32.

[93] Hegen M, Keith JC, Jr., Collins M, Nickerson-Nutter CL. Utility of animal models for identification of potential therapeutics for rheumatoid arthritis. Ann Rheum Dis 2008; 67(11): 1505-15.

[94] Qian M, Bai SA, Brogdon B, Wu JT, Liu RQ, Covington MB, et al. Pharmacokinetics and pharmacodynamics of DPC 333 ((2R)-2((3R)-3-amino-3 44-[2-methyl-4-quinolinyl) methoxy] phenyl\}-2 oxopyrrolidinyl)-N-hydroxy-4-methylpentanamide)), a potent and selective inhibitor of tumor necrosis factor alpha-converting enzyme in rodents, dogs, chimpanzees, and humans. Drug Metab Dispos 2007; 35(10): 1916-25

[95] Conway JG, Andrews RC, Beaudet B, Bickett DM, Boncek V, Brodie TA, et al. Inhibition of tumor necrosis factor-alpha (TNFalpha) production and arthritis in the rat by GW3333, a dual inhibitor of TNF-alpha-converting enzyme and matrix metalloproteinases. J Pharmacol Exp Ther 2001; 298(3): 900-8.

[96] Weber CR, Turner JR. Inflammatory bowel disease: is it really just another break in the wall? Gut 2007; 56(1): 6-8.

[97] Ardizzone S, Bianchi Porro G. Biologic therapy for inflammatory bowel disease. Drugs 2005; 65(16): 2253-86.

[98] Kolios G, Valatas V, Ward SG. Nitric oxide in inflammatory bowel disease: a universal messenger in an unsolved puzzle. Immunology 2004; 113(4): 427-37.

[99] Brynskov J, Foegh P, Pedersen G, Ellervik C, Kirkegaard T, Bingham A, et al. Tumour necrosis factor alpha converting enzyme (TACE) activity in the colonic mucosa of patients with inflammatory bowel disease. Gut 2002; 51(1): 37-43.

[100] Colon AL, Menchen LA, Hurtado O, De Cristobal J, Lizasoain I, Leza JC, et al. Implication of TNF-alpha convertase (TACE/ ADAM17) in inducible nitric oxide synthase expression and inflammation in an experimental model of colitis. Cytokine 2001; 16(6): 220-6.

[101] Feigin VL. Stroke epidemiology in the developing world. Lancet 2005; 365(9478): 2160-1.

[102] Lovering F, Zhang Y. Therapeutic potential of TACE inhibitors in stroke. Curr Drug Targets CNS Neurol Disord 2005; 4(2): 161-8.

[103] Planas AM, Gorina R, Chamorro A. Signalling pathways mediating inflammatory responses in brain ischaemia. Biochem Soc Trans 2006; 34(Pt 6): 1267-70.

[104] Wang AM, Creasey AA, Ladner MB, Lin LS, Strickler JS, Van Arsdell JN, et al. Molecular cloning of the complementary DNA for human tumor necrosis factor. Science 1985; 228: 149-54.

[105] Tang ZY, Loss G, Carmody I, Cohen AJ. TIMP-3 ameliorates hepatic ischemia/reperfusion injury through inhibition of tumor ne- 
crosis factor-alpha-converting enzyme activity in rats. Transplantation 2006; 82(11): 1518-23.

[106] Kermarrec N, Selloum S, Plantefeve G, Chosidow D, Paoletti X, Lopez A, et al. Regulation of peritoneal and systemic neutrophilderived tumor necrosis factor-alpha release in patients with severe peritonitis: role of tumor necrosis factor-alpha converting enzyme cleavage. Crit Care Med 2005; 33(6): 1359-64.

[107] Dehmel T, Janke A, Hartung HP, Goebel HH, Wiendl H, Kieseier BC. The cell-specific expression of metalloproteinase-disintegrins (ADAMs) in inflammatory myopathies. Neurobiol Dis 2007; 25(3): 665-74.

[108] Bostanci N, Emingil G, Afacan B, Han B, Ilgenli T, Atilla G, et al. Tumor necrosis factor-alpha-converting enzyme (TACE) levels in periodontal diseases. J Dent Res 2008; 87(3): 273-7.

[109] Hung TH, Chen SF, Hsu JJ, Hsieh CC, Hsueh S, Hsieh TT. Tumour necrosis factor-alpha converting enzyme in human gestational tissues from pregnancies complicated by chorioamnionitis. Placenta 2006; 27(9-10): 996-1006.

[110] Serwin AB, Sokolowska M, Chodynicka B. Tumour necrosis factor alpha (TNF-alpha)-converting enzyme (TACE) and soluble TNFalpha receptor type 1 in psoriasis patients treated with narrowband ultraviolet B. Photodermatol Photoimmunol Photomed 2007; 23(4): 130-4.

[111] Moriyama H, Tsukida T, Inoue Y, Yokota K, Yoshino K, Kondo $\mathrm{H}$, et al. Azasugar-based MMP/ADAM inhibitors as antipsoriatic agents. J Med Chem 2004; 47(8): 1930-8.

[112] Plumb J, McQuaid S, Cross AK, Surr J, Haddock G, Bunning RA, et al. Upregulation of ADAM-17 expression in active lesions in multiple sclerosis. Mult Scler 2006; 12(4): 375-85.

[113] Jackson LF, Qiu TH, Sunnarborg SW, Chang A, Zhang C, Patterson C, et al. Defective valvulogenesis in HB-EGF and TACE-null mice is associated with aberrant BMP signaling. Embo J 2003; 22(11): 2704-16.

[114] Satoh M, Nakamura M, Satoh H, Saitoh H, Segawa I, Hiramori K. Expression of tumor necrosis factor-alpha--converting enzyme and tumor necrosis factor-alpha in human myocarditis. J Am Coll Cardiol 2000; 36(4): 1288-94.

[115] Canault M, Peiretti F, Kopp F, Bonardo B, Bonzi MF, Coudeyre $\mathrm{JC}$, et al. The TNF alpha converting enzyme (TACE/ADAM17) is expressed in the atherosclerotic lesions of apolipoprotein Edeficient mice: possible contribution to elevated plasma levels of soluble TNF alpha receptors. Atherosclerosis 2006; 187(1): 82-91.

[116] Satoh H, Nakamura M, Satoh M, Nakajima T, Izumoto H, Maesawa $\mathrm{C}$, et al. Expression and localization of tumour necrosis factor-alpha and its converting enzyme in human abdominal aortic aneurysm. Clin Sci (Lond) 2004; 106(3): 301-6.

[117] Satoh M, Ishikawa Y, Itoh T, Minami Y, Takahashi Y, Nakamura $\mathrm{M}$. The expression of TNF-alpha converting enzyme at the site of ruptured plaques in patients with acute myocardial infarction. Eur $\mathbf{J}$ Clin Invest 2008; 38(2): 97-105.

[118] Lauring AS, Overbaugh J. Evidence that an IRES within the Notch 2 coding region can direct expression of a nuclear form of the protein. Mol Cell 2000; 6: 939-45.

[119] Shah BH, Catt KJ. TACE-dependent EGF receptor activation in angiotensin-II-induced kidney disease. Trends Pharmacol Sci 2006; 27(5): 235-7.

[120] Lautrette A, Li S, Alili R, Sunnarborg SW, Burtin M, Lee DC, et al. Angiotensin II and EGF receptor cross-talk in chronic kidney diseases: a new therapeutic approach. Nat Med 2005; 11(8): 86774

[121] Berry MA, Hargadon B, Shelley M, Parker D, Shaw DE, Green $\mathrm{RH}$, et al. Evidence of a role of tumor necrosis factor alpha in refractory asthma. N Engl J Med 2006; 354(7): 697-708.

[122] Greene C, Lowe G, Taggart C, Gallagher P, McElvaney N, O'Neill S. Tumor necrosis factor-alpha-converting enzyme: its role in community-acquired pneumonia. J Infect Dis 2002; 186(12): 17906.

[123] Ju CR, Xia XZ, Chen RC. Expressions of tumor necrosis factorconverting enzyme and ErbB3 in rats with chronic obstructive pulmonary disease. Chin Med J (Engl) 2007; 120(17): 1505-10.

[124] Federici M, Hribal ML, Menghini R, Kanno H, Marchetti V, Porzio $\mathrm{O}$, et al. Timp3 deficiency in insulin receptor-haploinsufficient mice promotes diabetes and vascular inflammation via increased TNF-alpha. J Clin Invest 2005; 115(12): 3494-505.
[125] Togashi N, Ura N, Higashiura K, Murakami H, Shimamoto K. Effect of TNF-alpha--converting enzyme inhibitor on insulin resistance in fructose-fed rats. Hypertension 2002; 39(2 Pt 2): 578-80.

[126] Voros G, Maquoi E, Collen D, Lijnen HR. Differential expression of plasminogen activator inhibitor-1, tumor necrosis factor-alpha, TNF-alpha converting enzyme and ADAMTS family members in murine fat territories. Biochim Biophys Acta 2003; 1625(1): 36-42.

[127] Serino M, Menghini R, Fiorentino L, Amoruso R, Mauriello A, Lauro D, et al. Mice heterozygous for tumor necrosis factor-alpha converting enzyme are protected from obesity-induced insulin resistance and diabetes. Diabetes 2007; 56(10): 2541-6.

[128] Worley JR, Hughes DA, Dozio N, Gavrilovic J, Sampson MJ. Low density lipoprotein from patients with Type 2 diabetes increases expression of monocyte matrix metalloproteinase and ADAM metalloproteinase genes. Cardiovasc Diabetol 2007; 6: 21.

[129] Alwayn IP, Andersson C, Lee S, Arsenault DA, Bistrian BR, Gura $\mathrm{KM}$, et al. Inhibition of matrix metalloproteinases increases PPARalpha and IL-6 and prevents dietary-induced hepatic steatosis and injury in a murine model. Am J Physiol Gastrointest Liver Physiol 2006; 291(6): G1011-9.

[130] Verbeek MM, Ruiter DJ, de Waal RM. The role of amyloid in the pathogenesis of Alzheimer's disease. Biol Chem 1997; 378(9): 937 50 .

[131] Postina R, Schroeder A, Dewachter I, Bohl J, Schmitt U, Kojro E, et al. A disintegrin-metalloproteinase prevents amyloid plaque formation and hippocampal defects in an Alzheimer disease mouse model. J Clin Invest 2004; 113(10): 1456-64.

[132] Hooper NM, Turner AJ. The search for alpha-secretase and its potential as a therapeutic approach to Alzheimer s disease. Curr Med Chem 2002; 9(11): 1107-19.

[133] Gottschalk C, Malberg K, Arndt M, Schmitt J, Roessner A, Schultze D, et al. Matrix metalloproteinases and TACE play a role in the pathogenesis of endometriosis. Adv Exp Med Biol 2000; 477: 483-6.

[134] Shubayev VI, Myers RR. Endoneurial remodeling by TNFalphand TNFalpha-releasing proteases. A spatial and temporal colocalization study in painful neuropathy. J Peripher Nerv Syst 2002; 7(1): 28-36.

[135] Madrigal JL, Hurtado O, Moro MA, Lizasoain I, Lorenzo P, Castrillo A, et al. The increase in TNF-alpha levels is implicated in NF-kappaB activation and inducible nitric oxide synthase expression in brain cortex after immobilization stress. Neuropsychopharmacology 2002; 26(2): 155-63.

[136] Bohgaki T, Amasaki Y, Nishimura N, Bohgaki M, Yamashita Y, Nishio M, et al. Up regulated expression of tumour necrosis factor \{alpha\} converting enzyme in peripheral monocytes of patients with early systemic sclerosis. Ann Rheum Dis 2005; 64(8): 116573.

[137] Kurz M, Pischel H, Hartung HP, Kieseier BC. Tumor necrosis factor-alpha-converting enzyme is expressed in the inflamed peripheral nervous system. J Peripher Nerv Syst 2005; 10(3): 311-8.

[138] Teles RM, Antunes SL, Jardim MR, Oliveira AL, Nery JA, Sales AM, et al. Expression of metalloproteinases (MMP-2, MMP-9, and TACE) and TNF-alpha in the nerves of leprosy patients. J Peripher Nerv Syst 2007; 12(3): 195-204.

[139] Fiorucci S, Antonelli E, Migliorati G, Santucci L, Morelli O, Federici $\mathrm{B}$, et al. TNFalpha processing enzyme inhibitors prevent aspirin-induced TNFalpha release and protect against gastric mucosal injury in rats. Aliment Pharmacol Ther 1998; 12(11): 113953.

[140] Leib SL, Clements JM, Lindberg RL, Heimgartner C, Loeffler JM, Pfister LA, et al. Inhibition of matrix metalloproteinases and tumour necrosis factor alpha converting enzyme as adjuvant therapy in pneumococcal meningitis. Brain 2001; 124(Pt 9): 1734-42.

[141] Koff JL, Shao MX, Kim S, Ueki IF, Nadel JA. Pseudomonas lipopolysaccharide accelerates wound repair via activation of a novel epithelial cell signaling cascade. J Immunol 2006; 177(12): 8693-700.

[142] Ingram RN, Orth P, Strickland CL, Le HV, Madison V, Beyer BM. Stabilization of the autoproteolysis of TNF-alpha converting enzyme (TACE) results in a novel crystal form suitable for structurebased drug design studies. Protein Eng Des Sel 2006; 19(4): 15561 .

[143] Dekkers PE, Lauw FN, ten Hove T, te Velde AA, Lumley P, Becherer D, et al. The effect of a metalloproteinase inhibitor (GI5402) 
on tumor necrosis factor-alpha (TNF-alpha) and TNF-alpha receptors during human endotoxemia. Blood 1999; 94(7): 2252-8.

[144] Coussens LM, Fingleton B, Matrisian LM. Matrix Metalloproteinase Inhibitors and Cancer--Trials and Tribulations. Science 2002; 295(5564): 2387-92

[145] Lopez-Otin C, Matrisian LM. Emerging roles of proteases in tumour suppression. Nat Rev Cancer 2007; 7(10): 800-8.

[146] Bandarage UK, Wang T, Come JH, Perola E, Wei Y, Rao BG. Novel thiol-based TACE inhibitors. Part 2: Rational design, synthesis, and SAR of thiol-containing aryl sulfones. Bioorg Med Chem Lett 2008; 18(1): 44-8.

[147] Condon JS, Joseph-McCarthy D, Levin JI, Lombart HG, Lovering FE, Sun L, et al. Identification of potent and selective TACE inhibitors via the S1 pocket. Bioorg Med Chem Lett 2007; 17(1): 349.

[148] Duan JJ, Lu Z, Xue CB, He X, Seng JL, Roderick JJ, et al. Discovery of N-hydroxy-2-(2-oxo-3-pyrrolidinyl)acetamides as potent and selective inhibitors of tumor necrosis factor-alpha converting enzyme (TACE). Bioorg Med Chem Lett 2003; 13(12): 2035-40.

[149] Witters L, Scherle P, Friedman S, Fridman J, Caulder E, Newton R, et al. Synergistic inhibition with a dual epidermal growth factor receptor/HER-2/neu tyrosine kinase inhibitor and a disintegrin and metalloprotease inhibitor. Cancer Res 2008; 68(17): 7083-9.

[150] Moss ML, Jin CS-L, Milla ME, Burkhart W, Carter HL, Chen W-J, et al. Cloning of a disintegrin metalloproteinase that processes precursor tumour-necrosis factor- $\alpha$. Nature 1997; 385: 733-6.

[151] Sunnarborg SW, Hinkle CL, Stevenson M, Russell WE, Raska CS, Peschon JJ, et al. Tumor necrosis factor-alpha converting enzyme (TACE) regulates epidermal growth factor receptor ligand availability. J Biol Chem 2002; [epub ahead of print].

[152] Sahin U, Weskamp G, Kelly K, Zhou HM, Higashiyama S, Peschon J, et al. Distinct roles for ADAM10 and ADAM17 in ectodomain shedding of six EGFR ligands. J Cell Biol 2004; 164(5): 769-79.

[153] Hinkle CL, Sunnarborg SW, Loiselle D, Parker CE, Stevenson M, Russell WE, et al. Selective roles for tumor necrosis factor alphaconverting enzyme/ADAM17 in the shedding of the epidermal growth factor receptor ligand family: the juxtamembrane stalk determines cleavage efficiency. J Biol Chem 2004; 279(23): 2417988.

[154] Sahin U, Blobel CP. Ectodomain shedding of the EGF-receptor ligand epigen is mediated by ADAM17. FEBS Lett 2007; 581(1): 41-4.

[155] Montero JC, Yuste L, Diaz-Rodriguez E, Esparis-Ogando A, Pandiella A. Differential shedding of transmembrane neuregulin isoforms by the tumor necrosis factor-alpha-converting enzyme. Mol Cell Neurosci 2000; 16(5): 631-48.

[156] Merlos-Suárez A, Ruiz-Paz S, Baselga J, Arribas J. Metalloprotease-dependent proTGF-a ectodomain shedding in the absence of TACE. J Biol Chem 2001; 276: 48510-7.

[157] Wang Y, Kim KA, Kim JH, Sul HS. Pref-1, a preadipocyte secreted factor that inhibits adipogenesis. J Nutr 2006; 136(12): 2953-6.

[158] Garton KJ, Gough PJ, Blobel CP, Murphy G, Greaves DR, Dempsey PJ, et al. Tumor necrosis factor-alpha-converting enzyme (ADAM17) mediates the cleavage and shedding of fractalkine (CX3CL1). J Biol Chem 2001; 276(41): 37993-8001.

[159] Zhu L, Bergmeier W, Wu J, Jiang H, Stalker TJ, Cieslak M, et al. Regulated surface expression and shedding support a dual role for semaphorin 4D in platelet responses to vascular injury. Proc Natl Acad Sci U S A 2007; 104(5): 1621-6.

[160] Li N, Wang Y, Forbes K, Vignali KM, Heale BS, Saftig P, et al. Metalloproteases regulate T-cell proliferation and effector function via LAG-3. Embo J 2007; 26(2): 494-504.

[161] Dyczynska E, Sun D, Yi H, Sehara-Fujisawa A, Blobel CP, Zolkiewska A. Proteolytic processing of delta-like 1 by ADAM proteases. J Biol Chem 2007; 282(1): 436-44.

[162] Kawaguchi N, Horiuchi K, Becherer JD, Toyama Y, Besmer P, Blobel CP. Different ADAMs have distinct influences on Kit ligand processing: phorbol-ester-stimulated ectodomain shedding of Kitl1 by ADAM17 is reduced by ADAM19. J Cell Sci 2007; 120(Pt 6): 943-52.

[163] Waldhauer I, Goehlsdorf D, Gieseke F, Weinschenk T, Wittenbrink M, Ludwig A, et al. Tumor-associated MICA is shed by ADAM proteases. Cancer Res 2008; 68(15): 6368-76.
[164] Weskamp G, Schlondorff J, Lum L, Becherer JD, Kim TW, Saftig $\mathrm{P}$, et al. Evidence for a critical role of the tumor necrosis factor alpha convertase (TACE) in ectodomain shedding of the p75 neurotrophin receptor (p75NTR). J Biol Chem 2004; 279(6): 4241-9.

[165] Althoff K, Reddy P, Voltz N, Rose-John S, Müllberg J. Shedding of interleukin-6 receptor and tumor necrosis factor alpha. Contribution of the stalk sequence to the cleavage pattern of transmembrane proteins. Eur J Biochem 2000; 267: 2624-31.

[166] Budagian V, Bulanova E, Orinska Z, Ludwig A, Rose-John S, Saftig P, et al. Natural soluble interleukin-15Ralpha is generated by cleavage that involves the tumor necrosis factor-alpha-converting enzyme (TACE/ADAM17). J Biol Chem 2004; 279(39): 40368-75.

[167] Diaz-Rodriguez E, Cabrera N, Esparis-Ogando A, Montero JC, Pandiella A. Cleavage of the TrkA neurotrophin receptor by multiple metalloproteases generates signalling-competent truncated forms. Eur J Neurosci 1999; 11: 1421-30.

[168] Wang X, He K, Gerhart M, Huang Y, Jiang J, Paxton RJ, et al. Metalloprotease-mediated GH receptor proteolysis and GHBP shedding. Determination of extracellular domain stem region cleavage site. J Biol Chem 2002; 277(52): 50510-9.

[169] Rovida E, Paccagnini A, Del Rosso M, Peschon J, Dello Sbarba P. TNF-alpha-converting enzyme cleaves the macrophage colonystimulating factor receptor in macrophages undergoing activation. J Immunol 2001; 166: 1583-9.

[170] Guo L, Eisenman JR, Mahimkar RM, Peschon JJ, Paxton RJ, Black $\mathrm{RA}$, et al. A proteomic approach for the identification of cellsurface proteins shed by metalloproteases. Mol Cell Proteomics 2002; 1(1): 30-6.

[171] Ruhe JE, Streit S, Hart S, Ullrich A. EGFR signaling leads to downregulation of PTP-LAR via TACE-mediated proteolytic processing. Cell Signal 2006; 18(9): 1515-27.

[172] Qu D, Wang Y, Esmon NL, Esmon CT. Regulated endothelial protein $\mathrm{C}$ receptor shedding is mediated by tumor necrosis factoralpha converting enzyme/ADAM17. J Thromb Haemost 2007; 5(2): 395-402.

[173] Cho RW, Park JM, Wolff SB, Xu D, Hopf C, Kim JA, et al. mGluR1/5-dependent long-term depression requires the regulated ectodomain cleavage of neuronal pentraxin NPR by TACE. Neuron 2008; 57(6): 858-71.

[174] Rio C, Buxbaum JD, Peschon JJ, Corfas G. Tumor Necrosis Factor--converting Enzyme Is Required for Cleavage of erbB4/HER4. J Biol Chem 2000; 275: 10379-87.

[175] Brou C, Logeat F, Gupta N, Bessia C, LeBail O, Doedens JR, et al. A novel proteolytic cleavage involved in Notch signaling: the role of the disintegrin-metalloprotease TACE. Mol Cell 2000; 5(2): 207-16.

[176] Hansen HP, Dietrich S, Kisseleva T, Mokros T, Mentlein R, Lange $\mathrm{HH}$, et al. CD30 shedding from Karpas 299 lymphoma cells is mediated by TNF-alpha-converting enzyme. J Immunol 2000; 165 : 6703-9.

[177] Contin C, Pitard V, Itai T, Nagata S, Moreau JF, DechanetMerville J. Membrane-anchored CD40 is processed by the tumor necrosis factor-alpha-converting enzyme. Implications for CD40 signaling. J Biol Chem 2003; 278(35): 32801-9.

[178] Bergmeier W, Piffath CL, Cheng G, Dole VS, Zhang Y, von Andrian UH, et al. Tumor necrosis factor-alpha-converting enzyme (ADAM17) mediates GPIbalpha shedding from platelets in vitro and in vivo. Circ Res 2004; 95(7): 677-83.

[179] Kalus I, Bormann U, Mzoughi M, Schachner M, Kleene R. Proteolytic cleavage of the neural cell adhesion molecule by ADAM17/ TACE is involved in neurite outgrowth. J Neurochem 2006; 98(1): 78-88.

[180] Maretzky T, Schulte M, Ludwig A, Rose-John S, Blobel C, Hartmann D, et al. L1 is sequentially processed by two differently activated metalloproteases and presenilin/gamma-secretase and regulates neural cell adhesion, cell migration, and neurite outgrowth. Mol Cell Biol 2005; 25(20): 9040-53.

[181] Tanabe Y, Kasahara T, Momoi T, Fujita E. Neuronal RA175/ SynCAM1 isoforms are processed by tumor necrosis factor-alphaconverting enzyme (TACE)/ADAM17-like proteases. Neurosci Lett 2008; 444(1): 16-21.

[182] Buxbaum JD, Liu KN, Luo Y, Slack JL, Stocking KL, Peschon JJ, et al. Evidence that tumor necrosis factor alpha converting enzyme is involved in regulated alpha-secretase cleavage of the Alzheimer amyloid protein precursor. J Biol Chem 1998; 273(43): 27765-7. 
[183] Endres K, Postina R, Schroeder A, Mueller U, Fahrenholz F. Shedding of the amyloid precursor protein-like protein APLP2 by disintegrin-metalloproteinases. Febs J 2005; 272(22): 5808-20.

[184] Dolnik O, Volchkova V, Garten W, Carbonnelle C, Becker S, Kahnt J, et al. Ectodomain shedding of the glycoprotein GP of Ebola virus. Embo J 2004; 23(10): 2175-84.

[185] Zatovicova M, Sedlakova O, Svastova E, Ohradanova A, Ciampor $\mathrm{F}$, Arribas $\mathrm{J}$, et al. Ectodomain shedding of the hypoxia-induced carbonic anhydrase IX is a metalloprotease-dependent process regulated by TACE/ADAM17. Br J Cancer 2005; 93(11): 1267-76.

[186] Vincent B, Paitel E, Saftig P, Frobert Y, Hartmann D, De Strooper $\mathrm{B}$, et al. The disintegrins ADAM10 and TACE contribute to the constitutive and phorbol ester-regulated normal cleavage of the cellular prion protein. J Biol Chem 2001; 276(41): 37743-6.

[187] Chen CD, Podvin S, Gillespie E, Leeman SE, Abraham CR. Insulin stimulates the cleavage and release of the extracellular domain of Klotho by ADAM10 and ADAM17. Proc Natl Acad Sci U S A 2007; 104(50): 19796-801.

[188] Thathiah A, Blobel CP, Carson DD. Tumor necrosis factor-alpha converting enzyme/ADAM 17 mediates MUC1 shedding. J Biol Chem 2003; 278(5): 3386-94.

[189] Esselens CW, Malapeira J, Colome N, Moss M, Canals F, Arribas J. Metastasis-associated C4.4A, a GPI-anchored protein cleaved by ADAM10 and ADAM17. Biol Chem 2008.

[190] Brown PD. Matrix metalloproteinase inhibitors: a novel class of anticancer agents. Adv Enzyme Regul 1995; 35: 293-301.

[191] Barlaam B, Bird TG, Lambert-Van Der Brempt C, Campbell D, Foster SJ, Maciewicz R. New alpha-substituted succinate-based hydroxamic acids as TNFalpha convertase inhibitors. J Med Chem 1999; 42(23): 4890-908.

[192] Hurtado O, Lizasoain I, Fernandez-Tome P, Alvarez-Barrientos A, Leza JC, Lorenzo P, et al. TACE/ADAM17-TNF-alpha pathway in rat cortical cultures after exposure to oxygen-glucose deprivation or glutamate. J Cereb Blood Flow Metab 2002; 22(5): 576-85.

[193] Grootveld M, McDermott MF. BMS-561392. Bristol-Myers Squibb. Curr Opin Investig Drugs 2003 May; 4(5): 598-602.

[194] Tsukida T, Moriyama H, Inoue Y, Kondo H, Yoshino K, Nishimura S. Synthesis and biological activity of selective azasugarbased TACE inhibitors. Bioorg Med Chem Lett 2004; 14(6): 156972 .

[195] Levin JI, Chen JM, Du MT, Nelson FC, Killar LM, Skala S, et al. Anthranilate sulfonamide hydroxamate TACE inhibitors. Part 2: SAR of the acetylenic P1' group. Bioorg Med Chem Lett 2002; 12(8): 1199-202.

[196] Xue CB, He X, Corbett RL, Roderick J, Wasserman ZR, Liu RQ, et $a l$. Discovery of macrocyclic hydroxamic acids containing biphenylmethyl derivatives at $\mathrm{P1}$ ', a series of selective TNF-alpha converting enzyme inhibitors with potent cellular activity in the inhibition of TNF-alpha release. J Med Chem 2001; 44(21): 3351-4.

[197] Letavic MA, Axt MZ, Barberia JT, Carty TJ, Danley DE, Geoghegan KF, et al. Synthesis and biological activity of selective pipecolic acid-based TNF-alpha converting enzyme (TACE) inhibitors. Bioorg Med Chem Lett 2002; 12(10): 1387-90.

[198] Levin JI, Chen JM, Cheung K, Cole D, Crago C, Santos ED, et al. Acetylenic TACE inhibitors. Part 1. SAR of the acyclic sulfonamide hydroxamates. Bioorg Med Chem Lett 2003; 13(16): 2799803.

[199] Duan JJ, Chen L, Wasserman ZR, Lu Z, Liu RQ, Covington MB, et $a l$. Discovery of gamma-lactam hydroxamic acids as selective inhibitors of tumor necrosis factor alpha converting enzyme: design, synthesis, and structure-activity relationships. J Med Chem 2002; 45(23): 4954-7.

[200] Sawa M, Kurokawa K, Inoue Y, Kondo H, Yoshino K. Discovery of selective phosphonamide-based inhibitors of tumor necrosis factor-alpha converting enzyme (TACE). Bioorg Med Chem Lett 2003; 13(12): 2021-4.

[201] Cherney RJ, King BW, Gilmore JL, Liu RQ, Covington MB, Duan $\mathrm{JJ}$, et al. Conversion of potent MMP inhibitors into selective TACE inhibitors. Bioorg Med Chem Lett 2006; 16(4): 1028-31.

[202] Holms J, Mast K, Marcotte P, Elmore I, Li J, Pease L, et al. Discovery of selective hydroxamic acid inhibitors of tumor necrosis factor-alpha converting enzyme. Bioorg Med Chem Lett 2001; 11(22): 2907-10.

[203] Kamei N, Tanaka T, Kawai K, Miyawaki K, Okuyama A, Murakami Y, et al. Reverse hydroxamate-based selective TACE inhibitors. Bioorg Med Chem Lett 2004; 14(11): 2897-900.
[204] Cherney RJ, Duan JJ, Voss ME, Chen L, Wang L, Meyer DT, et al. Design, synthesis, and evaluation of benzothiadiazepine hydroxamates as selective tumor necrosis factor-alpha converting enzyme inhibitors. J Med Chem 2003; 46(10): 1811-23.

[205] Venkatesan AM, Davis JM, Grosu GT, Baker J, Zask A, Levin JI, et al. Synthesis and structure-activity relationships of 4-alkynyloxy phenyl sulfanyl, sulfinyl, and sulfonyl alkyl hydroxamates as tumor necrosis factor-alpha converting enzyme and matrix metalloproteinase inhibitors. J Med Chem 2004; 47(25): 6255-69.

[206] Blacker M, Noe MC, Carty TJ, Goodyer CG, LeBlanc AC. Effect of tumor necrosis factor-alpha converting enzyme (TACE) and metalloprotease inhibitor on amyloid precursor protein metabolism in human neurons. J Neurochem 2002; 83(6): 1349-57.

[207] Wang X, Feuerstein GZ, Xu L, Wang H, Schumacher WA, Ogletree ML, et al. Inhibition of tumor necrosis factor-alphaconverting enzyme by a selective antagonist protects brain from focal ischemic injury in rats. Mol Pharmacol 2004; 65(4): 890-6.

[208] Mirastschijski U, Johannesson K, Jeppsson B, Agren MS. Effect of a matrix metalloproteinase activity and TNF-alpha converting enzyme inhibitor on intra-abdominal adhesions. Eur Surg Res 2005; 37(1): 68-75.

[209] Levin JI, Gu Y, Nelson FC, Zask A, DiJoseph JF, Sharr MA, et al. Heteroaryl and cycloalkyl sulfonamide hydroxamic acid inhibitors of matrix metalloproteinases. Bioorg Med Chem Lett 2001; 11(2): $239-42$.

[210] Hundhausen C, Misztela D, Berkhout TA, Broadway N, Saftig P, Reiss $\mathrm{K}$, et al. The disintegrin-like metalloproteinase ADAM10 is involved in constitutive cleavage of CX3CL1 (fractalkine) and regulates CX3CL1-mediated cell-cell adhesion. Blood 2003; 102(4): 1186-95.

[211] Rabinowitz MH, Andrews RC, Becherer JD, Bickett DM, Bubacz DG, Conway JG, et al. Design of selective and soluble inhibitors of tumor necrosis factor-alpha converting enzyme (TACE). J Med Chem 2001; 44(24): 4252-67.

[212] Niu X, Umland S, Ingram R, Beyer BM, Liu YH, Sun J, et al. IK682, a tight binding inhibitor of TACE. Arch Biochem Biophys 2006; 451(1): 43-50.

[213] Xue CB, He X, Roderick J, Corbett RL, Duan JJ, Liu RQ, et al. Rational design, synthesis and structure-activity relationships of a cyclic succinate series of TNF-alpha converting enzyme inhibitors. Part 2: lead optimization. Bioorg Med Chem Lett 2003; 13(24): 4299-304.

[214] Morimoto Y, Nishikawa K, Ohashi M. KB-R7785, a novel matrix metalloproteinase inhibitor, exerts its antidiabetic effect by inhibiting tumor necrosis factor-alpha production. Life Sci 1997; 61(8): 795-803.

[215] Huang A, Joseph-McCarthy D, Lovering F, Sun L, Wang W, Xu $\mathrm{W}$, et al. Structure-based design of TACE selective inhibitors: manipulations in the S1'-S3' pocket. Bioorg Med Chem 2007; 15(18): 6170-81.

[216] Trifilieff A, Walker C, Keller T, Kottirsch G, Neumann U. Pharmacological profile of PKF242-484 and PKF241-466, novel dual inhibitors of TNF-alpha converting enzyme and matrix metalloproteinases, in models of airway inflammation. Br J Pharmacol 2002 135(7): 1655-64

[217] Beck G, Bottomley G, Bradshaw D, Brewster M, Broadhurst M, Devos R, et al. (E)-2(R)-[1(S)-(Hydroxycarbamoyl)-4-phenyl-3butenyl]-2'-isobutyl-2'-(methanesulfonyl)-4-methylvalerohydrazide (Ro 32-7315), a Selective and Orally Active Inhibitor of Tumor Necrosis Factor-alpha Convertase. J Pharmacol Exp Ther 2002; 302(1): 390-6.

[218] Mohler K, Sleath PR, Fitzner JN, Cerretti DP, Alderson M, Kerwar SS, et al. Protection against a lethal dose of endotoxin by an inhibitor of tumour necrosis factor processing. Nature 1994; 370: 218-20.

[219] Arribas J, Coodly L, Vollmer P, Kishimoto TK, Rose-John S, Massague J. Diverse cell surface protein ectodomains are shed by a system sensitive to metalloprotease inhibitors. J Biol Chem 1996; 271(19): 11376-82

[220] Bennett T, Edwards B, Sklar L, S. R. Sulfhydryl regulation of Lselectin shedding: phenylarsine oxide promotes activationindependent L-selectin shedding from leukocytes. J Immunol 2000; 164: 4120-9.

[221] Hooper NM, Karran EH, Turner AJ. Membrane protein secretases. Biochem J 1997; 321 ( Pt 2): 265-79. 
[222] Thabet MM, Huizinga TW. Drug evaluation: apratastat, a novel TACE/MMP inhibitor for rheumatoid arthritis. Curr Opin Investig Drugs 2006; 7(11): 1014-9.

[223] Zhang Y, Hegen M, Xu J, Keith JC, Jr., Jin G, Du X, et al. Characterization of (2R,3S)-2-([[4-(2-butynyloxy)phenyl]sulfonyl]amino)N,3-dihydroxybutanamide, a potent and selective inhibitor of TNFalpha converting enzyme. Int Immunopharmacol 2004; 4(14): 1845-57.

[224] Zhang Y, Xu J, Levin J, Hegen M, Li G, Robertshaw H, et al. Identification and characterization of 4-[[4-(2-butynyloxy)phenyl] sulfonyl]-N-hydroxy-2,2-dimethyl-(3S)thiomorpho linecarboxamide (TMI-1), a novel dual tumor necrosis factor-alpha- converting enzyme/matrix metalloprotease inhibitor for the treatment of rheumatoid arthritis. J Pharmacol Exp Ther 2004; 309(1): 348-55.

[225] Dell KM, Nemo R, Sweeney WE, Jr., Levin JI, Frost P, Avner ED A novel inhibitor of tumor necrosis factor-alpha converting enzyme ameliorates polycystic kidney disease. Kidney Int 2001; 60(4): $1240-8$

[226] McCarthy AA. Exelixis: integrated drug-discovery and development platform for human therapeutics. Chem Biol 2005; 12(4): 407-8. 